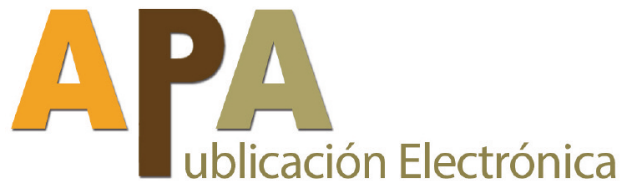

WWW 2469-0228
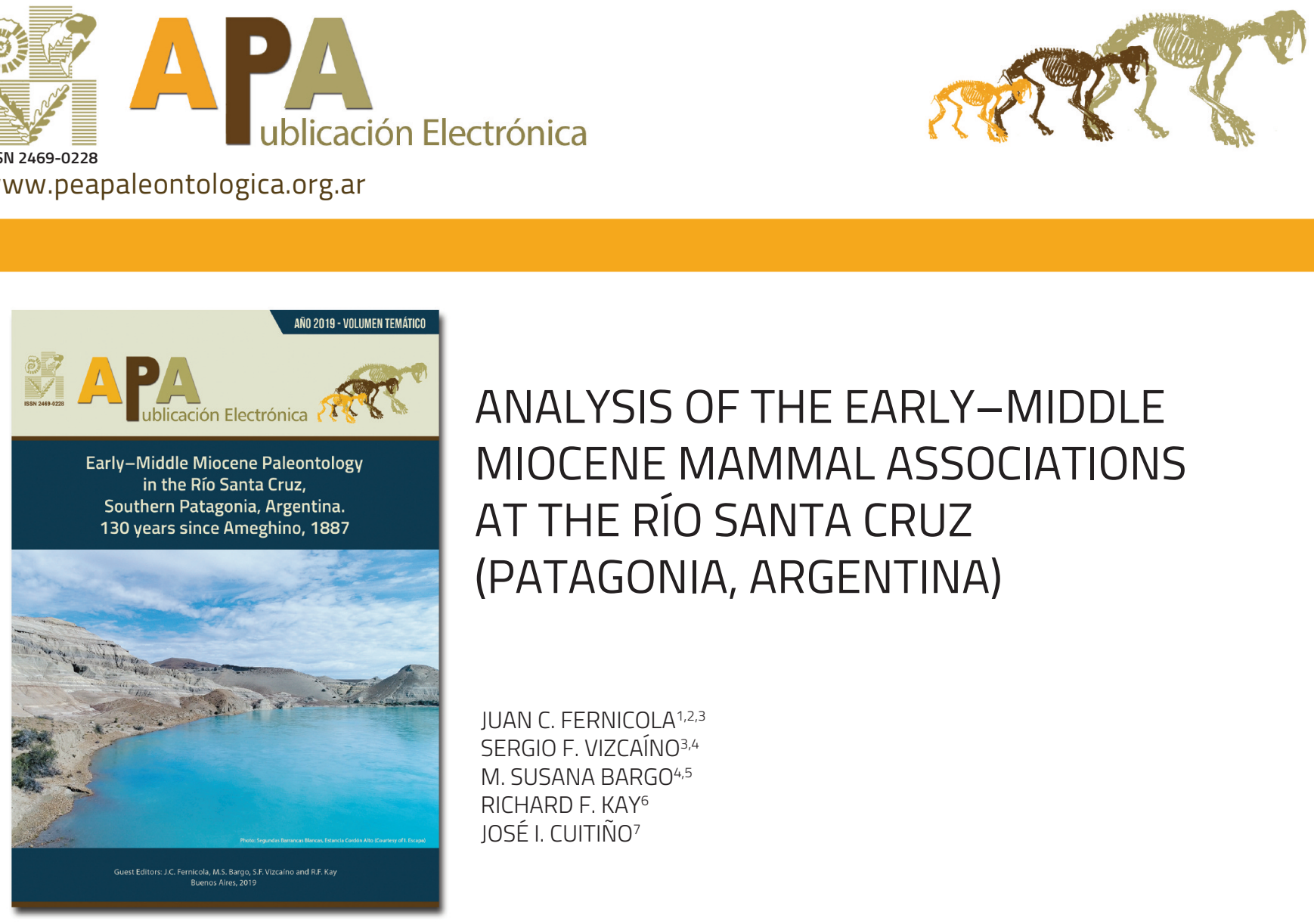

\section{ANALYSIS OF THE EARLY-MIDDLE MIOCENE MAMMAL ASSOCIATIONS AT THE RÍO SANTA CRUZ (PATAGONIA, ARGENTINA)}

\author{
JUAN C. FERNICOLA $1,2,3$ \\ SERGIO F. VIZCAÍNO 3,4 \\ M. SUSANA BARGO ${ }^{4,5}$ \\ RICHARD F. KAY ${ }^{6}$ \\ JOSÉ I. CUITIÑO'
}

\begin{abstract}
\Sección Paleontología de Vertebrados, Museo Argentino de Ciencias Naturales "Bernardino Rivadavia". Av. Ángel Gallardo 470, 1405DJR Ciudad Autónoma de Buenos Aires, Argentina.

²Universidad Nacional de Luján, Departamento de Ciencias Básicas. Ruta 5 y Av. Constitución, 6700 Luján, Buenos Aires, Argentina.

${ }^{3}$ Comisión Nacional de Investigaciones Científicas y Técnicas (CONICET).

${ }^{4}$ División Paleontología Vertebrados, Museo de La Plata, Unidades de Investigación Anexo Museo, Facultad de Ciencias Naturales y Museo. Av. 60 y 122,1900 La Plata, Argentina.

${ }^{5}$ Comisión de Investigaciones Científicas de la Provincia de Buenos Aires (CIC).

${ }^{6}$ Department of Evolutionary Anthropology and Division of Earth and Ocean Sciences. Box 90383, Duke University, Durham, North Carolina, 27708 USA. 'Instituto Patagónico de Geología y Paleontología (IPGP, CCT CONICET-CENPAT). Boulevard Brown 2915, 9120 Puerto Madryn, Chubut, Argentina.
\end{abstract}

Recibido: 28 de septiembre 2019 - Aceptado: 1 de noviembre 2019

Para citar este artículo: Juan C. Fernicola, Sergio F. Vizcaíno, M. Susana Bargo, Richard F. Kay, and José l. Cuitiño (2019). Analysis of the Early-Middle Miocene mammal associations at the Río Santa Cruz (Patagonia, Argentina). Publicación Electrónica de la Asociación Paleontológica Argentina 19 (2): 239-259.

Link a este artículo: http://dx.doi.org/10.5710/PEAPA.01.11.2019.309

DESPLAZARSE HACIA ABAJO PARA ACCEDER AL ARTÍCULO

Asociación Paleontológica Argentina Maipú $6451^{\circ}$ piso, C1006ACG, Buenos Aires República Argentina Tel/Fax (54-11) 4326-7563

Otros artículos en Publicación Electrónica de la APA 19(2):

\section{L.M. Pérez et al.}

DIPLODON CF. COLHUAPIENSIS (BIVALVIAHYRIIDAE) IN SANTA CRUZ FORMATION (EARLY-MIDDLE MIOCENE), AT THE RÍO SANTA CRUZ, PATAGONIA, ARGENTINA. STRATIGRAPHIC AND PALEOENVIRONMENTAL CONSIDERATIONS

\section{M.S. Bargo et al.}

EARLY MIOCENE SLOTHS (XENARTHRA, FOLIVORA) FROM THE RÍO SANTA CRUZ VALLEY (SOUTHERN PATAGONIA, ARGENTINA). AMEGHINO, 1887 REVISITED b: www.apaleontologica.org.ar
M. Arnal et al.

MIOCENE CAVIOMORPHS FROM THE RÍO SANTA CRUZ (ARGENTINEAN PATAGONIA): AN UPDATE OF THIS CHARACTERISTIC RODENT FAUNA 


\title{
ANALYSIS OF THE EARLY-MIDDLE MIOCENE MAMMAL ASSOCIATIONS AT THE RÍO SANTA CRUZ (PATAGONIA, ARGENTINA)
}

\author{
JUAN C. FERNICOLA1,2,3, SERGIO F. VIZCAIINO3,4, M. SUSANA BARGO ${ }^{4,5}$, RICHARD F. KAY6, AND JOSÉ I. CUITIÑO7
}

1Sección Paleontología de Vertebrados, Museo Argentino de Ciencias Naturales "Bernardino Rivadavia". Av. Ángel Gallardo 470, 1405DJR Ciudad Autónoma de Buenos Aires, Argentina.jctano@yahoo.com

²Universidad Nacional de Luján, Departamento de Ciencias Básicas. Ruta 5 y Av. Constitución, 6700 Luján, Buenos Aires, Argentina. ${ }^{3}$ Comisión Nacional de Investigaciones Científicas y Técnicas (CONICET).

${ }^{4}$ División Paleontología Vertebrados, Museo de La Plata, Unidades de Investigación Anexo Museo, Facultad de Ciencias Naturales y Museo. Av. 60 y 122,1900 La Plata, Argentina.vizcaino@fcnym.unlp.edu.ar; msbargo@fcnym.unlp.edu.ar

${ }^{5}$ Comisión de Investigaciones Científicas de la Provincia de Buenos Aires (CIC).

${ }^{6}$ Department of Evolutionary Anthropology and Division of Earth and Ocean Sciences. Box 90383, Duke University, Durham, North Carolina, 27708 USA. richard.kay@duke.edu

7Instituto Patagónico de Geología y Paleontología (IPGP, CCT CONICET-CENPAT). Boulevard Brown 2915, 9120 Puerto Madryn, Chubut, Argentina.

jcuitino@cenpat-conicet.gob.ar

Abstract. The Santa Cruz Formation (SCF) records high latitude terrestrial paleoecosystems in the Southern Hemisphere during Burdigalianearly Langhian times (Early-Middle Miocene). Mammalian fossils from Río Santa Cruz (RSC) localities were first collected in the late $19^{\text {th }}$ century, forming the basis for the Santacrucian South American Land Mammal Age. New collections permitt an update of the SCF mammalian species along the RSC. The total taxonomic richness is 95 mammalian species. Many species considered by Ameghino as exclusive for the older Notohippidian stage at similar latitude in the west, are not in fact so. The taxonomic richness in three localities along the RSC is substantially different: 47 species from Barrancas Blancas (BB), 60 from Segundas Barrancas Blancas (SBB) and nine from Yaten Huageno. The faunal composition between BB and SBB is also different: they share 31 species, of which six are present only at BB and 20 only at SBB. More than $85 \%$ of all RSC species are also found at Atlantic coastal exposures of the SCF. In spite of BB ( 17.04-16.49 Ma) being closer in age to coastal exposures, and SBB fossils $(\sim 16.46-15.63 \mathrm{Ma})$ being younger than the coastal localities $(\sim 17.80-16.30 \mathrm{Ma})$, the greatest similarity is between SBB and the coast. Faunal differences among the localities may be accounted for local variation in climatic and environmental factors. Previously proposed Santacrucian biozones should be set aside. The exposures of the SCF along the RSC should be considered as the type area of this unit and the Santacrucian fauna.

Key words. Santacrucian. Burdigalian. Fossil vertebrates. Taxonomic richness. Biozone.

Resumen. ANÁLISIS DE LAS ASOCIACIONES DE MAMIIFEROS FÓSILES DEL MIOCENO TEMPRANO-MEDIO DEL RÍO SANTA CRUZ (PATAGONIA, ARGENTINA). La Formación Santa Cruz (FSC) registra paleoecosistemas terrestres de alta latitud en el hemisferio sur durante el BurdigalienseLanghiense temprano (Mioceno Temprano-Medio). Los primeros mamíferos fósiles del Río Santa Cruz (RSC) fueron recolectados a fines del siglo 19 y constituyeron la base de la Edad Mamífero Santacrucense. Nuevas colecciones permitieron actualizar la lista de especies santacrucenses del RSC. La riqueza taxonómica total es de 95 especies. Muchas especies consideradas por Ameghino como exclusivas del más antiguo Piso Notohippidense no lo son en realidad. La riqueza taxonómica en las tres localidades del RSC es sustancialmente diferente: 47 especies en Barrancas Blancas (BB), 60 en Segundas Barrancas Blancas (SBB) y nueve en Yaten Huageno. La composición faunística también es diferente entre BB y SBB; comparten 31 especies, seis presentes solo en BB y 20 solo en SBB. Más del 85 \% de las especies de mamíferos RSC también se encuentran en la FSC de la costa atlántica. Aunque BB ( 17,04-16,49 Ma) es más próxima cronológicamente a las exposiciones costeras y los fósiles de SBB ( 16,46-15,63 Ma) son más jóvenes, se registra mayor similitud entre SBB y la costa ( 17,80-16,30 Ma). Las diferencias faunísticas entre las localidades podrían explicarse por la variación local de factores climáticos y ambientales. Las biozonas propuestas previamente deben ser dejadas de lado. Las exposiciones de la FSC a lo largo del RSC deben considerarse como el área tipo de la unidad y la fauna santacrucense.

Palabras clave. Santacrucense. Burdigaliense. Vertebrados fósiles. Riqueza taxonómica. Biozona. 
The Santa CRuz Formation (SCF) is an Early-Middle Miocene continental sedimentary succession distributed in a large area of southern Patagonia that contains one of the richest fossil vertebrate assemblages of the Cenozoic of South America and formed the basis of the Santacrucian South American Land Mammal Age (SALMA; Pascual et al., 1965). Its conceptualization as a regional faunal association goes back to the $19^{\text {th }}$ century (Ameghino, 1889).

The first formal geological and paleontological survey of the SCF was carried out on outcrops along the Río Santa Cruz (RSC) in 1887 by Carlos Ameghino, then "Traveling Naturalist" of the Museo de La Plata (Fernicola, 2011a,b; Vizcaíno, 2011; Vizcaíno et al., 2013; Fernicola et al., 2019a). One of Ameghino's main objectives was to increase the number of fossils that F.P. Moreno (then lifetime Director of the Museo de La Plata since 1884) had collected in that region during an expedition to Southern Patagonia in 1876 and 1877 (Moreno, 1879; Fernicola et al., 2019a). Carlos Ameghino returned to the Museo de La Plata with more than 2000 fossil specimens that were immediately studied by his brother Florentino, who named 110 new species of mammals (Ameghino, 1887a), dramatically increasing the number of Santacrucian taxa from the 12 described earlier (Fernicola et al., 2019a and references therein). When F. Ameghino was relieved of his duties at the Museo de La Plata in 1888, he appropriated a part of the Santacrucian collection made in 1887 (see Fernicola, 2011a,b), among which were a number of type specimens. Carlos Ameghino was expelled from the Museo by Moreno in 1888, but he continued collecting fossils from Patagonia for his brother until 1903 (Vizcaíno et al., 2013). Ameghino (1889) proposed 15 additional species based on specimens from the RSC. Using these collections, he conceptualized a Fauna Santacruceña coming from the Piso Santacruceño. Between 1888 and 1889, Moreno launched new Museo de La Plata expeditions to collect fossils from the RSC and placed the Swiss geologist Alcides Mercerat in charge of the paleontological collections in the Museo de La Plata. Between 1887 and 1894, approximately 500 added taxa from the SCF were proposed by Ameghino and Mercerat, of which about 120 type specimens came from the RSC (Fernicola et al., 2019a).

Later, Ameghino (1900-02, 1906) subdivided his Piso Santacruceño into a supposed older notohippidéen and a younger santacruzéen stages. In the process, he transferred to the Notohippidian 15 species originally described for the $\mathrm{RSC}$, thereby obscuring the real distinction between the two stages (Fernicola et al., 2014, 2019a).

Meanwhile, new exposures of the SCF along the Atlantic coast discovered in 1890-91, unlike those of the RSC, produced more complete specimens redirecting the fieldwork and academic study of Santacrucian faunas away from the RSC (Vizcaíno, 2011; Vizcaíno et al., 2012a, 2013; Fernicola et al., 2019a). As a consequence, collecting in the RSC exposures was neglected for more than a century. In fact, it took more than 120 years to reidentify the precise location of the sites prospected by Carlos Ameghino in 1887 (Fernicola et al., 2014). This "coastal" approach has since dominated our thinking about the SCF and its fossils chronologically and geographically. Indeed, Marshall et al. (1983, p. 28; 1986 , p. 450) considered the formation's outcrops at the coastal region of Monte León, near the mouth of the RSC, to be the ..." nominal type locality"... of the SCF and the Santacrucian SALMA, when in fact it was not (see below).

The embedded inconsistencies in the scientific literature about the distinctness of the Santacrucian and Notohippidian stages, and the incorrect identification of the type region for the Santacrucian fauna as it was originally conceived by Ameghino (1889), added to the effects it has had on comparisons with other Early and Middle Miocene Patagonian faunas, has lead us to reopen the neglected geological and paleontological study of the formation along the river (Fernicola et al., 2019a). The preliminary results of this new study are reported in this volume (Fernicola et al., 2019b).

Our objective in what follows is to compile and analyze an updated mammalian taxonomic list of the SCF at the RSC in order to compare it with earlier studies of the RSC, comparing taxonomic richness of the different localities along the RSC, and assessing the value of the biostratigraphic units (biozones) of the Santacrucian fauna as a whole based upon its type locality.

\section{GEOLOGIC SETTING}

The Santa Cruz Formation is situated within the AustralMagallanes geological basin (Dalziel et al., 1974). This unit corresponds to the younger part of the foreland basin stage and its accumulation is thought to be strongly controlled by 


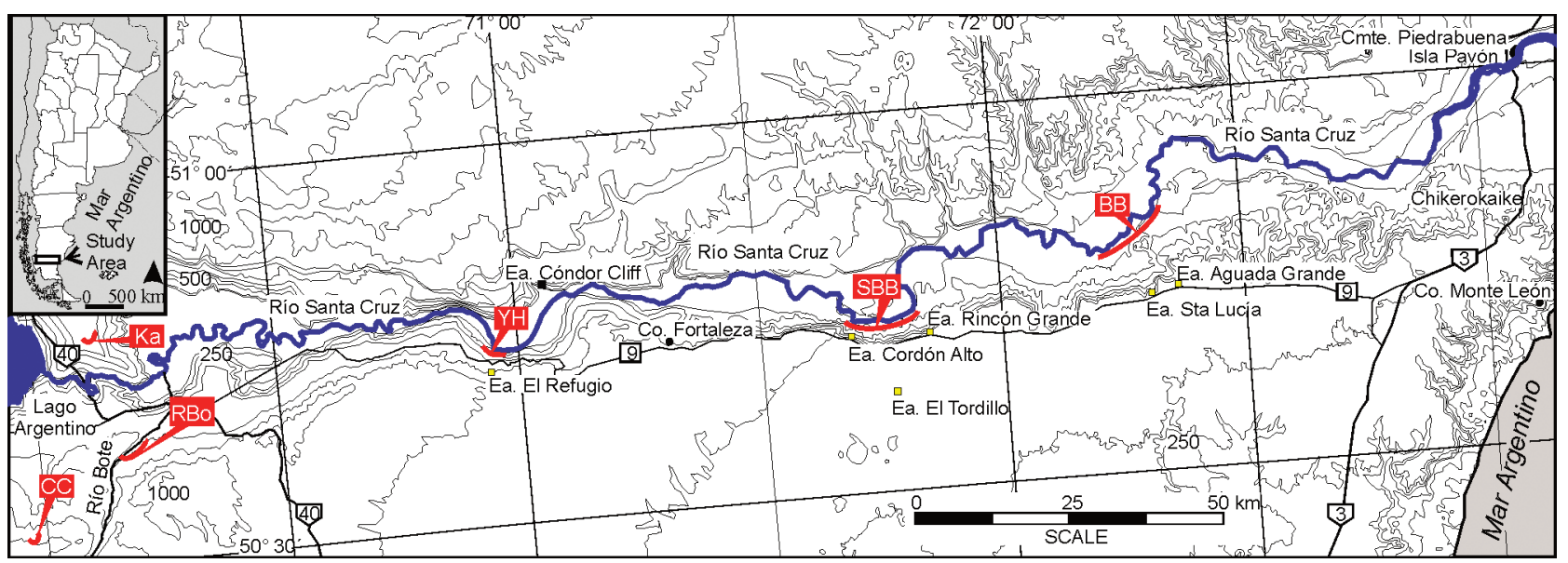

Figure 1. Map of the Río Santa Cruz with the prospected localities and estancias mentioned in the text. BB, Barrancas Blancas; CC, Cerro Centinela; Ea., Estancia; Ka, Karaiken; RBo, Río Bote; SBB, Segundas Barrancas Blancas; YH, Yaten Huageno. Modified from Fernicola et al. (2014).

Andean tectonics and arc volcanism (Fosdick et al., 2013; Cuitiño et al., 2016; Ghiglione et al., 2016; Parras and Cuitiño, 2018). Owing to the wide and continuous exposures and the richness of its contained fossils, the SCF represents the most important record of high latitude terrestrial paleoenvironments, paleoclimates, and ecosystems of the Southern Hemisphere during Burdigalian-early Langhian (e.g., Vizcaíno et al., 2012a,b; Raigemborn et al., 2018; Cuitiño et al., 2019a).

The RSC originates in the Lago Argentino and flows through a deeply incised valley stretching $230 \mathrm{~km}$ from west to east across the continent. Along the valley's margins, three Miocene sedimentary units can be recognized: (1) the shallow marine Early Miocene Estancia 25 de Mayo Formation (Cuitiño and Scasso, 2010; = the Centinela Formation); (2) the shallow marine to deltaic Monte León Formation (Sacomani and Panza, 2011; Parras and Cuitiño, 2018); and (3) the terrestrial Early-Middle Miocene Santa Cruz Formation (Tauber et al., 2008; Sacomani and Panza, 2011; Cobos et al., 2014; Fernicola et al., 2014; Cuitiño et al., 2016, 2019b). The latter is well exposed in three localities from which we made an extensive fossil collection denominated, from east to west, Barrancas Blancas, Segundas Barrancas Blancas, and Yaten Huageno (Fig. 1). The location, stratigraphy, sedimentology, and geochronology for the SCF in these localities are summarized in Fernicola et al. (2014) and Cuitiño et al. (2016, 2019b).

The age of the SCF is well constrained radiometrically.
For the coastal zone of southeast of the Province of Santa Cruz the age of the unit is bracketed by means of $\mathrm{Ar}^{39} / \mathrm{Ar}^{40}$, high precision zircon $\mathrm{U} / \mathrm{Pb}$, and sedimentation rate estimations between $~ 17.8$ and 16.3 Ma (Burdigalian; Tejedor et al., 2006; Perkins et al., 2012; Trayler et al., 2019); in the RSC valley the unit is dated by means of U/Pb on zircons and estimated sedimentation rate between $\sim 17.45$ and 15.63 Ma (Burdigalian-early Langhian; Cuitiño et al., 2016).

Fernicola et al. (2014) and Cuitiño et al. (2016; 2019b) reconstructed the fossiliferous locations that Carlos Ameghino studied on the southern margin of the RSC in 1887. These localities, from east to west, are described in what follows.

\section{Barrancas Blancas (BB)}

Barrancas Blancas is an outcrop of approximately $6 \mathrm{~km}$ in length of horizontal strata from east (S $50^{\circ} 09^{\prime} 38.31^{\prime \prime}$ -

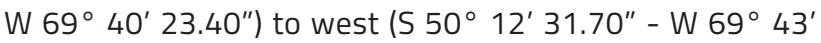
$\left.10.66^{\prime \prime}\right)$. The eastern limit of this exposure is located in Estancia Aguada Grande (EAG) and its western end is found in the Estancia Santa Lucía (ESL). In this region, the fossils were collected from EAG (= EAG2; see Cuitiño et al., 2019b) and ESL (= ESL section; see Cuitiño et al., 2019b). The Monte León Formation crops out at the eastern end of BB and grades transitionally into the SCF, the latter composed of nearly 100 m of well stratified, yellow to greenish siltstone and tabular claystone beds, with evidence of paleosol formation. In this part of SCF, sandstone beds are infrequent 

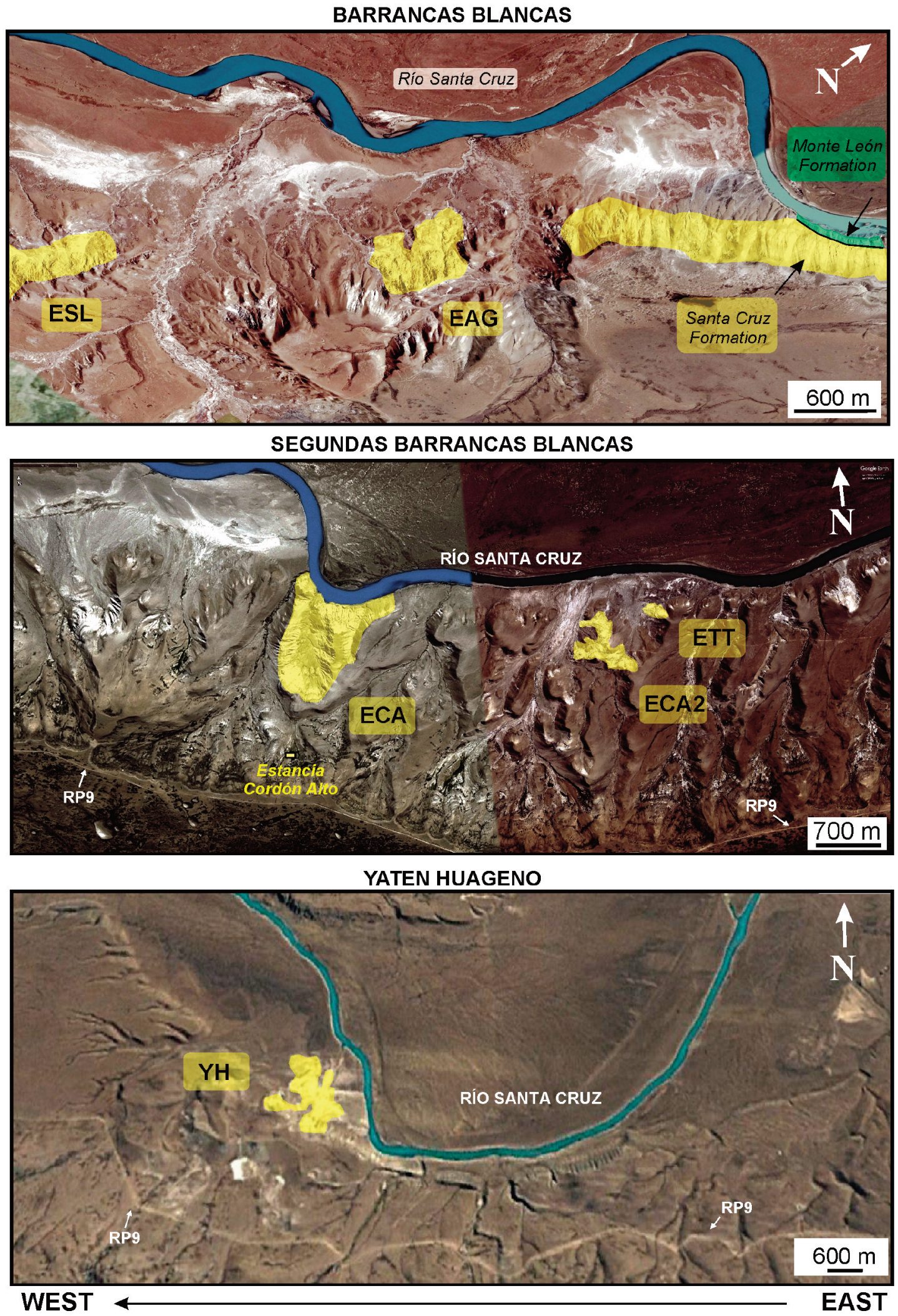

Figure 2. Satellite image (Google Earth TM; 2002) of the Barrancas Blancas, and Segundas Barrancas Blancas (Modified from Cuitiño et al., 2019b); and Yaten Huageno. Section of Monte Observación Member of the Monte León Formation and Santa Cruz Formation are highlighted in green and yellow, respectively. EAG, Estancia Aguada Grande Section; ESL, Estancia Santa Lucía Section; ECA, Estancia Cordón Alto Section; ECA2, Estancia Cordón Alto 2 Section; ETT, Estancia El Tordillo Section, YH, Yaten Huageno. 
and abundant pyroclastic material is observed mixed with the epiclastic material, as well as thick tuff beds. In the eastern part of this outcrop a tuff near the base of the SCF was dated at $17.04 \pm 0.55$ (Cuitiño et al., 2016: fig. 3D); this laterally continuous tuff is used as a marker bed to correlate with Section EAG, where it crops out at the base of the SCF. The ESL Section at BB is a small exposure located $3 \mathrm{~km}$ southwest of EAG (Fig. 2; Google Earth images). The correlation of this section with EAG is established from a local tuff layer located $45 \mathrm{~m}$ above the $17.04 \mathrm{Ma}$ tuff at (Cuitiño et al., 2019b: fig. 8).

\section{Segundas Barrancas Blancas (SBB)}

The SBB locality is a belt of $9 \mathrm{~km}$ of exposures in lands of Estancia Cordón Alto (ECA), Estancia El Tordillo (EET), and Estancia Rincón Grande (Fig. 2). Only the SCF crops out at SBB, not the Monte León Formation. Each exposure is identified from east to west as EET (= EET1, see Cuitiño et al., 2019b; S50 16' 43.00" - W 70 15' 9.90"), ECA2 (S 50 16' $55.96^{\prime \prime}-$ W $\left.70^{\circ} 15^{\prime} 47.33^{\prime \prime}\right)$, and ECA (= ECA 1, Cuitiño et al., 2019b, S $50^{\circ} 16^{\prime} 25.56^{\prime \prime}$ - W 70 18' 24.74"). The exposures lie at the bottom of the valley, where the river erodes its southern slope (Fig. 2). Here, SCF is composed of finegrained sediments deposited in a low-energy fluvial system. The sections are locally correlated using a tuff layer located near the base of the sections (CECA-2 tuff; Cuitiño et al., 2016: fig. 3C) and by distinctive tabular, laterally extensive yellow beds (Cuitiño et al., 2019b). The CECA-2 tuff layer was dated at the EET Section by Cuitiño et al. (2016) at $16.32 \pm 0.62 \mathrm{Ma}$.

\section{Yaten Huageno $(\mathrm{YH})$}

Yaten Huageno is an outcrop of about $2 \mathrm{~km}$ in length

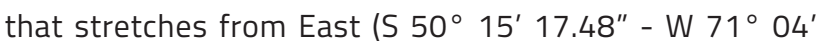
09.56") to West (S $50^{\circ} 15^{\prime} 40.74^{\prime \prime}$ - W 71 $03^{\prime} 48.81^{\prime \prime}$ ) within the Estancia El Refugio (Fig. 2). Only the SCF crops out here, which is composed of $80 \mathrm{~m}$ of brown and greenish siltstone, sandstone and tuff beds (Cuitiño et al., 2019b). For this section, a tuff layer located in the middle part of the section has been dated in $16.88 \pm 0.65 \mathrm{Ma}$ (Cuitiño et al., 2016: fig. 3B); by sedimentation rate the temporal range of this locality is between $\sim 17.22$ to $\sim 16.67 \mathrm{Ma}$.

\section{MATERIALS AND METHODS}

The specimens were collected by teams of 10-12 people during the Austral summers of 2013 and 2014. On average, they collected fossils during 20 days each season, from the localities BB, SBB, and YH. Almost all identifiable pieces were collected without size or taxonomic bias, and constitute more than 1900 specimens, which are permanently housed at the Museo Regional Provincial "Padre M. Jesús Molina" of Río Gallegos (Province of Santa Cruz, Argentina). The specimens are associated with geographic coordinates, stratigraphic provenance, and/or altitude above sea level.

The taxonomic identifications that form the basis of this paper are taken from the lists provided in this volume: Metatheria (Chornogubsky et al., 2019), Folivora (Bargo et al., 2019), Cingulata (Fernicola and Vizcaíno, 2019), Notoungulata and Astrapotheria (Fernández and Muñoz, 2019), Litopterna (Schmidt et al., 2019), Rodentia (Arnal et al., 2019), and Primates (Kay and Perry, 2019) (Fig 3.1-9).

We performed comparative analyses of mammalian taxonomic richness based on the presence/absence of species. We compared our new collections from the RSC with earlier collections, which we identify as the "old collections" from the RSC (Ameghino, 1885, 1887a; Mercerat, 1891; Cabrera, 1927; Pérez, 2010; Arnal, 2012; Arnal and Vucetich, 2015). We also compared the richness among the three localities BB, SBB, and $\mathrm{YH}$. As earlier publications did not discriminate among the three localities (e.g., Ameghino, 1887a) we considered only information from the new collections. Finally, we compared the taxonomic list of new collections with that of localities along Atlantic Coast (Monte León, Cerro Observatorio, Anfiteatro, Estancia la Costa, Cañadon Silva, Puesto la Costa, Monte Tigre, and Killik Aike Norte; Fernicola et al., 2019a: fig. 1) based on the latest available publications (Tauber, 1996, 1997a; Soria, 2001; Arnal, 2012; Kay et al., 2012; Arnal et al., 2017, 2019; Bargo et al., 2019).

Institutional abbreviations. MACN-A, Museo Argentino de Ciencias Naturales "Bernardino Rivadavia", Colección Nacional Ameghino, Buenos Aires, Argentina; MLP, Museo de La Plata, La Plata, Argentina; MPM-PV, Museo Regional Provincial "Padre M. Jesús Molina", Río Gallegos, Argentina. 


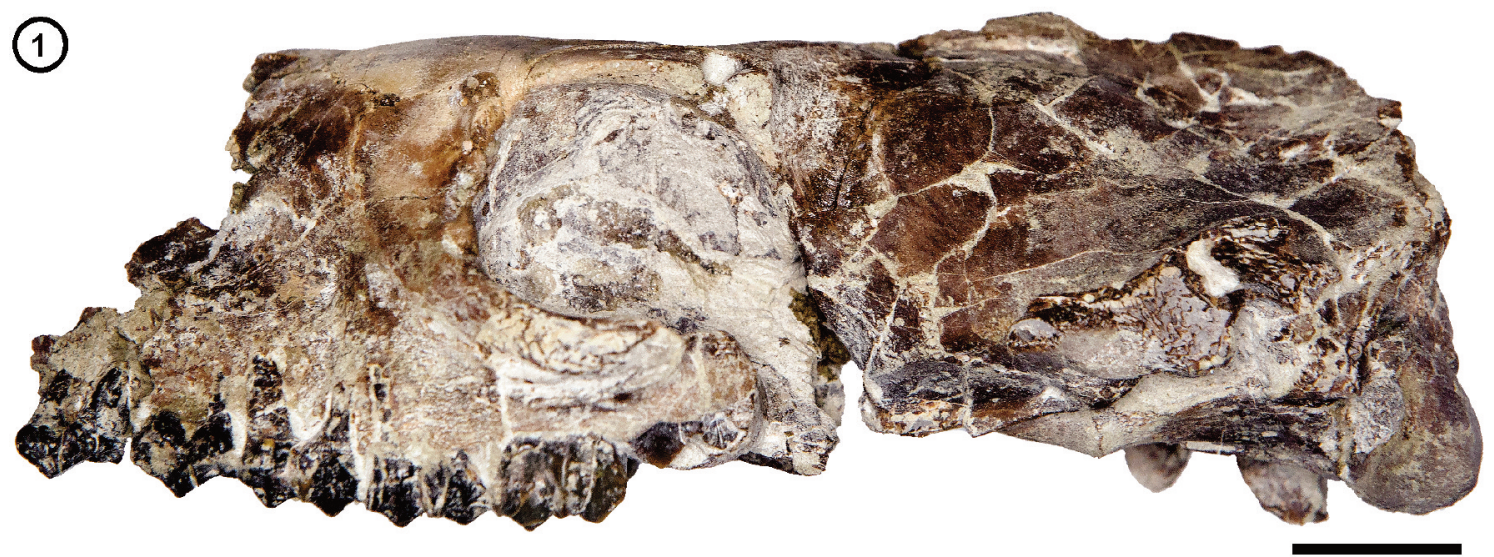

(2)

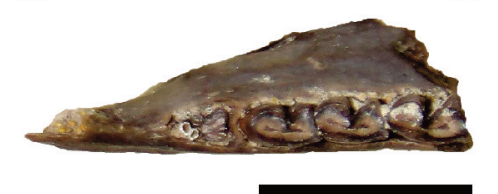

(5)
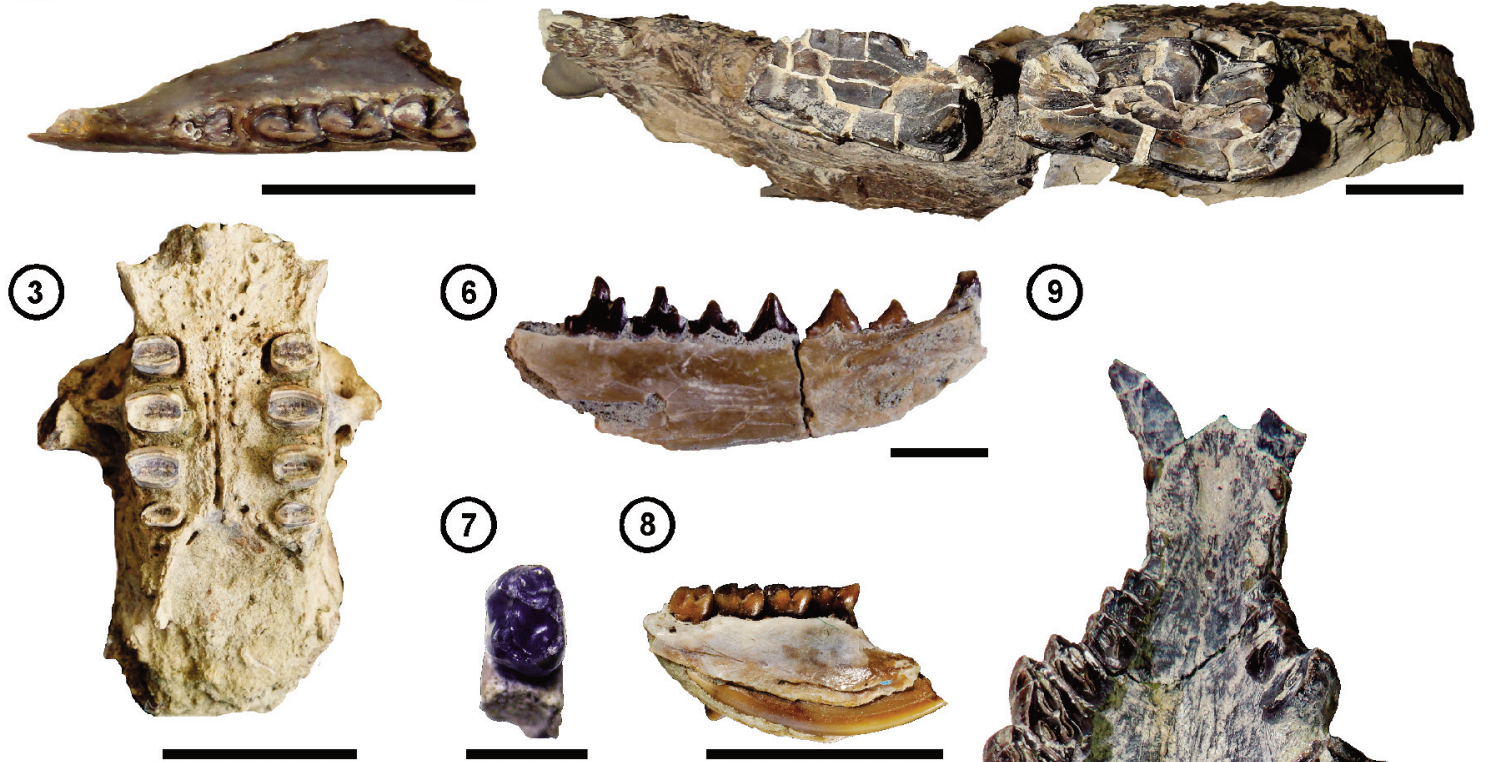

(6)

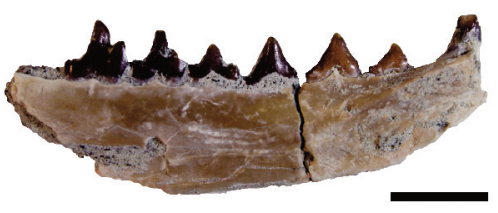

(9)

(4)

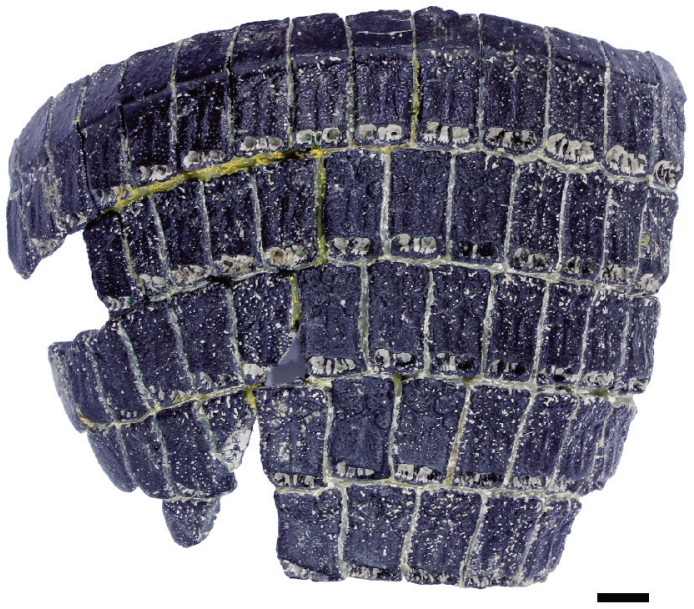

(8)
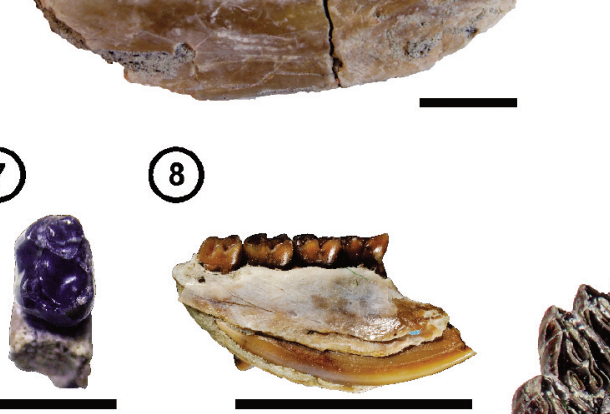

(7)
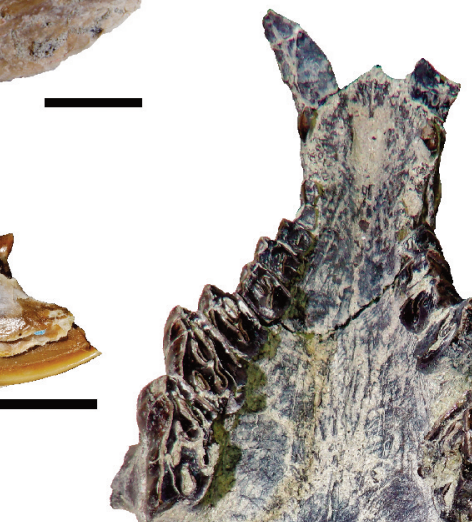

ancs
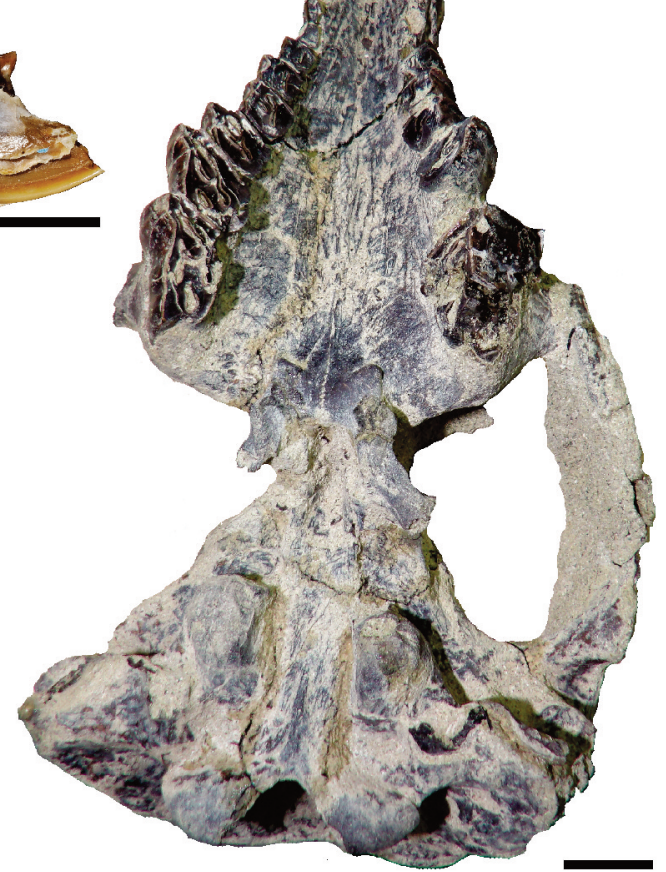

Figure 3. 1, Tetramerorhinus cingulatum, MPM-PV 19449, incomplete skull with left and right DP1-DP4 and M1, left lateral view; scale bar= $20 \mathrm{~mm}$; 2, Pachyrukhos moyani, MPM-PV 19917, right mandibular fragment with p2-m1, oclusal view; scale bar= $10 \mathrm{~mm}$; 3, Hapalops cf. elongatus, MPM-PV 19353, anterior portion of skull in palatal view; scale bar $=30 \mathrm{~mm}$; 4, Proeutatus oenophorus, MPM-PV 21023, portion of the pelvic shield; scale bar= $10 \mathrm{~mm}$; 5, Astrapotherium magnum, MPM-PV 19927, left mandibular fragment with m1-2, in oclusal view; scale bar= 20 mm; 6, Sipalocyon gracilis, MPM-PV 19413, lingual view; scale bar= 10 mm; 7, Homunculus vizcainoisp. nov., MPM-PV 19426, left m1, oclusal view; scale bar $=5 \mathrm{~mm} ; 8$, Acarechimys gracilis, MPM-PV 17430, left mandible with dp4-m3 in lingual view; scale bar= 10 mm; 9 , Adinotherium ovinum, MPM-PV 19717, almost complete skull with associated dentition in palatal view; scale bar= $20 \mathrm{~mm}$. 


\section{RESULTS}

Appendix 1 presents the taxonomic list of mammals recorded by us in the new RSC collections. Our new collection of fossil mammals consists of 540 specimens collected in BB, 1267 in SBB, and 21 in $\mathrm{YH}$. Species-level identifications were possible for 307 specimens at BB, 647 at SBB, and 11 at $\mathrm{YH}$ (Tab. 1). In total, this collection consists of 64 species, adding in six taxa identified at the genus or higher level only when this record implies at least the presence of one species (e.g., Eucinepeltus sp., Planopinae indet.). The breakdown is 10 species of metatherians (four Sparassodonta, five Paucituberculata, and one Microbiotheria), 12 species of xenarthrans (five Folivora and seven Cingulata), one astrapotherian species, nine notoungulate species (three Toxodontia and six Typotheria), seven litopterns species (six Proterotheriidae and one Macraucheniidae), 24 rodent species (11 Octodontoidea, two Erethizontoidea, five Cavioidea, and six Chinchilloidea), and one primate (Homunculidae).

Appendix 2 is a compilation of mammal species in the new collections of SCF at RSC, as reported in this volume (Fernicola et al., 2019b), compared with those previous reported from RSC. We also list the species present in the three localities at the RSC that are also recorded in outcrops of the SCF from the Atlantic Coast between National Park Monte León and Río Gallegos.

From the old collections as a whole, with the revised taxonomic identifications in this volume there are 79 species: 15 metatherians (six Sparassodonta, seven Paucituberculata, and two Microbiotheria), 16 xenarthrans (nine Folivora and seven Cingulata), two astrapotheres, 16 notoungulates (eight Toxodontia and eight Typotheria), five

TABLE 1 - Specimens and species recovered at BB, SBB, and YH

\begin{tabular}{lccc}
\hline Localities & $\begin{array}{c}\text { Total } N^{\circ} \\
\text { of specimens }\end{array}$ & $\begin{array}{c}\text { Specimens identified } \\
\text { at specific level }\end{array}$ & $\begin{array}{c}\text { Total } N^{\circ} \\
\text { of species }\end{array}$ \\
\hline BB & 540 & 307 & 37 \\
SBB & 1267 & 647 & 51 \\
YH & 21 & 11 & 7 \\
\hline Total & 1828 & 965 & - \\
\hline \hline
\end{tabular}

litopterns (four Proterotheriidae and one Macraucheniidae), and 25 Rodents (12 Octodontoidea, two Erethizontoidea, five Cavioidea, and six Chinchilloidea) (Appendix 2).

Combining the old and new collection lists the taxonomic richness rises to 95 mammalian taxa (Appendix 2). Chornogubsky et al. (2019) listed nine of the 15 species of metatherians from the old collections and a new record (Perathereutes pungens Ameghino, 1891), increasing the overall taxonomic richness to 16 species. Bargo et al. (2019) and Fernicola and Vizcaíno (2019) identified 12 taxa, of which only six were registered among the 16 species of xenarthrans in the old collections. The xenarthran taxonomic richness rises to 22 species, with new records of three sloths (Hapalops elongatus Ameghino, 1891, Xyophorus atlanticus Ameghino, 1891, Nematherium longirostris Ameghino, 1891, and a species of Planopinae), and two glyptodonts (Cochlops muricatus Ameghino, 1889 and Eucinepeltus sp. Ameghino 1891). Fernández and Muñoz (2019) identified one of the two previously reported species of Astrapotherium Burmeister, 1879 in the new collections, and identify seven of the 16 species of notoungulates in the new collections that also occur in the old collections. Litopterns are represented by seven species, adding two more, Tetramerorhinus lucarius Ameghino, 1894 and $T$. cingulatum (Ameghino, 1891), to the five recorded in the old collection list (Schmidt et al., 2019). Arnal et al. (2019) recognized 24 species of rodents, one less than in the old collections. But six taxa in our collections (Perimys incavatus Ameghino, 1902, "Eocardia" excavata Ameghino, 1891, Sciamys latidens Scott, 1905, Prospaniomys sp. nov.?, Dudumus sp. nov.?, and Acarechimys gracilis Ameghino, 1891) were not found in the old collections, increasing the taxonomic richness to 31 species. A primate identified in the new collections is a new species, Homunculus vizcainoi Kay and Perry, 2019, increasing the taxonomic richness to one species. Excluding the first records for the RSC, the total number of species shared between the old and new collections is 44, and the number of unshared species is 35 (Appendix 2).

In the new collections of RSC, SBB has the largest number of taxa (60: 51 species +8 species assignable to genus but of uncertain species + Planopinae indet.). For BB the numbers are smaller (47: 37 species + 10); at YH we recovered four cingulates, three rodents, one notoungulate, 
and Astrapotherium magnum Burmeister, 1879. Astrapotherium magnum is not certainly present in BB and SBB although several specimens represent an Astrapotherium of uncertain species (Fernández and Muñoz, 2019). The specific richness of BB and SBB show differences: of a total of 57 species identified for these localities, they share 31, six are present only at BB (two rodents, one litoptern, one notoungulate, and two cingulates) and 20 only at SBB (10 rodents, two litopterns, two notoungulates, three sloths, and three methaterians).

The great majority of fossil mammal species recorded in the new collections at SCR are also found at Atlantic coastal localities between Monte León and Killik Aike Norte. Of the 37 species identified in BB, 31 are also in the coastal localities (81\%), while of the 51 species identified in SBB, 47 (92\%) are in the coast as well. All seven species recorded in $\mathrm{YH}$ are found in coastal localities (Appendix 2).

\section{DISCUSSION}

\section{Taxonomic richness: old vs. new collections}

Until recently, a major challenge when comparing the taxonomic richness reported for the RSC is a consequence of confusion about the two subdivisions proposed by Ameghino (1900-02, 1906): his Piso Santacruceño was divided into a supposedly older étage notohippidéen in the West, and a younger étage santacruzéen from the RSC and the Atlantic coast. Fifteen of the 54 species said by Ameghino to be exclusively Notohippidian were collected by C. Ameghino in 1887 at the SCF's outcrops at Río Bote, a tributary of the RSC (Fernicola et al., 2014). Ameghino (1900-02) claimed that he was able to incorporate into his Notohippidian list, species that were founded more than 10 years earlier because his brother Carlos had provided the precise geographical position of each specimen. However, a review of the data in the Ameghino Catalog (preserved at MACN) does not support, in most cases, the exclusive western origin mentioned by Ameghino (1900-02). For example, the rodent Neoreomys indivisus Ameghino, 1887a (= Neoreomys australis, Kramarz, 2006) was considered by Ameghino (1900-02) as an exclusively Notohippidian species. However, the taxon was collected by C. Ameghino during his expedition to the barrancas of the RSC. Further complicating matters, another specimen of Neoreomys indivisus (MACN-A
4329-4337) is recorded in the Ameghino Catalog as being collected by Carlos Ameghino at Cerro Observatorio (= Monte Observación). Other Neoreomys indivisus specimens lack geographic information, so it is not possible to establish which could have come from the SCR, if any. A similar situation occurs with the notoungulate Adinotherium splendidum Ameghino, 1887a. This species was first collected from the RSC and, according to the Ameghino Catalog, other specimens (MACN-A 5364 and 5365) were collected at the coastal locality Puesto La Costa (= Corriguen Kaik, as recorded in the Ameghino Catalog) and at Cerro Observatorio (MACNA 5359). Other specimens of $A$. splendidum have no geographic information. These two cases are examples of marked contradictions between the species considered by Ameghino (1900-02, 1906) as exclusive for the Notohippidian, and the geographical distribution of the specimens assigned by him to those species in his catalog. In both cases it is possible that some specimens in the Ameghino Catalog without geographical information could have been collected in the Río Bote or in the Karaiken area, but no information has emerged to indicate that this is the case. What we do know from the Ameghino Catalog is that both species are not exclusive to the Notohippidian stage, because they are reported from areas where Ameghino only recognized a fauna of the Santacrucian stage. An additional but no less important issue is that in $1888 \mathrm{~F}$. Ameghino appropriated from the Museo de La Plata several specimens that had been collected by Carlos in 1887 (Fernicola, 2011a,b). The circumstances in which this removal occurred suggest that F. Ameghino did not carry with him any detailed information on the origin of the specimens that remained in the MLP, and we have not found this information in the Ameghino archives in the MACN. Thus, it is not clear how it was possible for Ameghino to assign geographical information to each of the specimens of 1887 still housed in the MLP when he did not have access to them (Fernicola, 2011a,b; Fernicola et al., 2019a). Finally, the problem of the geographic location of supposed Notohippidian species assemblage is not only with the 1887 collection. For example, Adinotherium robustum Ameghino, 1891, collected by Carlos Ameghino after 1887, was considered by Ameghino (1900-02) to be exclusively Notohippidian, but the Ameghino Catalog lists specimens MACN-A 407 and MACN-A 865 as being collected at 
Puesto La Costa, indicating that certainly it is not exclusively Notohippidian.

Certainly, the notoungulate Notohippus toxodontoides Ameghino, 1891 has so far been recorded only in outcrops of the SCF in the west near Lago Argentino (Ameghino, 1906; Marshall and Pascual, 1977; Fernicola et al., 2014; Cuitiño et al., 2016). Marshall and Pascual (1977) reported a Notohippidian assemblage from lower levels of the SCF at Karaiken, from which they recorded Notohippus toxodontoides. Simpson (1940) and Marshall et al. (1983) considered this assemblage as an early Santacrucian local fauna. According to Fleagle et al. (2012) the lowest levels of the Karaiken deposits correlate with the very lowest levels at Monte León, which would be consistent with primitive nature of the Karaiken fossils relative to those from the coast. Cuitiño et al. (2016) place that assemblage slightly younger than 18.5 Ma, but older than 17.8 Ma. Unlike Ameghino (1906), Marshall and Pascual (1977) report Santacrucian fauna from levels younger than 17.71 Ma (Fleagle et al., 2012; Cuitiño et al., 2016). Marshall and Pascual (1977) claim that Ameghino's specimens of Notohippus toxodontoides lack precise stratigraphic provenance and, therefore, cannot be assigned to one of these two faunal levels. They also described a Notohippidian assemblage recovered from the lower SFC levels at Cerro Centinela, $30 \mathrm{~km}$ southwest of the Río Bote section (Fig. 1), bracketed between 18.85 and 18.70 Ma (Cuitiño et al., 2016). Fernicola et al. (2014) and Cuitiño et al. (2016) recognized the presence of Notohippus toxodontoides in the lower levels of the SCF at Río Bote (at $\sim 18.20$ to 18.00). Considering Notohippus toxodontoides as a reference fossil, the Notohippidian would be older than the Santacrucian, as proposed by Ameghino (1900-02, 1906), which on the Atlantic coast its oldest levels are 17.80-17.45 Ma (Cuitiño et al., 2016). The part of the section of Karaiken above $17.71 \mathrm{Ma}$ (Perkins et al., 2012) would be synchronous with the lower levels of the SCF outcropping between Monte Leon and Puesto la Costa (at $\sim 17.80$ to $17.50 \mathrm{Ma}$ ) (Fig. 4). This scheme must be evaluated with the new taxonomic assignments of the specimens that we have collected in the upper levels of Río Bote and that are currently being studied by us.

The inclusion in the RSC taxonomic list of the taxa of 1887 and 1889 that Ameghino (1900-02, 1906) placed in the Notohippidian stage, and therefore in the western region of the Province of Santa Cruz, depends ultimately on a comprehensive historical analysis of each of those 15 taxa (Fernicola et al., 2019a). The same consideration applies to the remaining exclusively Notohippidian species identified by Ameghino (1900-02), the remains of which were collected after 1889. For these reasons, the taxonomic lists of Ameghino for the RSC should be taken only as a first approximation of the taxonomic richness in the western region. Clearly, only new faunal lists based on specimens collected in new fieldwork will produce a more accurate understanding of the taxonomic richness of RSC.

After taxonomic revisions, 79 mammalian species were recorded at the old collections of RSC (Appendix 2), not a number exceeding 100 as Ameghino originally supposed. This reduction is due to a great extent to synonymies proposed by several authors (e.g., Scott, 1903; Sinclair, 1909), and despite the establishment of several new RSC taxa (e.g., Cabrera, 1927; Arnal and Vucetich, 2015). At the specieslevel, the old and new collections share 44 species (Appendix 2). The 35 species not recorded in the new collections, may in part be an artifact because, as several authors conclude, several of the taxonomic groups presented here are taxonomically oversplit and require further revision (e.g., Litopterna, Schmidt et al., 2019; Folivora, Bargo et al., 2019; Notoungulata, Fernández and Muñoz, 2019). The difference may also be overestimated because of the quality of the fossils we recovered. We were able to assign many specimens only to the generic level, not the level of the species due to the absence of the diagnostic parts. For example, we recovered several specimens of Interatherium, but none can be assigned with certainty to any of the three species previously reported for the RSC (Fernández and Muñoz, 2019).

\section{Taxonomic richness of the RSC localities}

As we mentioned previously, the mammalian associations evaluated in this study correspond to BB, SBB and $\mathrm{YH}$. Unfortunately, at YH ( 17.22 -16.67 Ma; Cuitiño et al., 2016) we recovered only 21 specimens among which there are only nine species-level identifications (Appendix 2). The low number of specimens and species in this locality prevents us from considering it in the following discussion. It should be noted that $\mathrm{YH}$ is more coarse-grained (higher 
energy) and has the lowest areal exposure $\left(0.4 \mathrm{~km}^{2}\right)$ compared with BB $\left(1.35 \mathrm{~km}^{2}\right)$ and SBB $\left(1.5 \mathrm{~km}^{2}\right)$. We suppose that $\mathrm{YH}$ is the least fossiliferous locality because our sampling efforts were comparatively similar to that of SSB and BB. Notably, Carlos Ameghino in his fieldbook mentioned that $\mathrm{YH}$ was the most fossiliferous of all the localities of the RSC (in Rusconi, 1965). Nevertheless, Clemente Onelli, who visited the RSC, obtained similar result to ours (Brinkman and Vizcaíno, 2014), a fact that allow us to support our perception concerning this site.

With respect to taxonomic richness, SBB has a greater number of species than BB. Excluding the 31 species in common between the two localities, of the 26 remaining species, 20 are unique to SBB and six to BB. This interesting taxonomic difference should be understood within the framework of the temporal ranges of RSC species. According to the dates and sedimentation rates applied to the SBB deposits (Cuitiño et al., 2016) the sedimentary levels in SBB range from $\sim 16.46$ to $15.65 \mathrm{Ma}$, whereas those at $\mathrm{BB}$ have a time range between $\sim 17.05$ to 16.49 Ma (Cuitiño et al., 2016). Thus, the mammalian associations of both localities are time successive, temporally separate, and non-overlapping.

\section{Comparison with older levels of the SCF}

In spite of BB being closer in age to the older Atlantic coastal levels the SCF between Monte León and Río Gallegos, and SBB fossils being younger than the Atlantic coastal levels, the greatest similarity is between SBB and the coast (Appendix 2; Fig. 4). Nineteen of the 20 species present in SBB but absent in BB are present on the Atlantic coast. Twelve species occur at Anfiteatro - Puesto Estancia La Costa (Fernicola 2019a: fig. 5), in sedimentary levels older than those of BB ( 17.40 to $17.60 \mathrm{Ma}$; Cuitiño et al., 2016) (Appendix 2): Microbiotherium tehuelchum Ameghino, 1887a, Perathereutes pungens Ameghino, 1891, and Cladosictis patagonica Ameghino, 1887a (Metatheria); Xyophorus atlanticus (Pilosa); Adinotherium ovinum Owen, 1853 and Pachyrukhos moyani Ameghino, 1885 (Notoungulata); Tetramerorhinus cingulatum and Anisolophus floweri (Ameghino, 1887a) (Litopterna); and Acarechimys minutus (Ameghino, 1887a), Acarechimys constans (Ameghino, 1887a), Acaremys murinus Ameghino, 1887a, and Stichomys regularis Ameghino, 1887a
(Rodentia). The rodent Sciamys latidens, only known by its holotype, was recorded at SCF from Killik Aike Norte at levels older than BB ( 17.00-16.90 Ma; Cuitiño et al., 2016). With respect to the other species, four rodents Acarechimys gracilis, Prolagostomus pusillus Ameghino, 1887a, Pliolagostomus notatus Ameghino, 1887a and Schistomys erro Ameghino, 1887a, and the sloth Nematherium longirostris, were reported at the SCF from Cerro Observatorio, at sedimentary levels older than or synchronous to those of BB ( 17.8016.30 Ma; Cuitiño et al., 2016). The neotype of the sloth Schismotherium fractum Ameghino, 1887a quite possibly was collected in Monte León or Yegua Quemada (Racco et al., 2018) ( 17.80-16.20 Ma; Cuitiño et al., 2016) (Fig. 4).

The only SBB taxon not represented on the Atlantic coast corresponds to the rodent Dudumus sp. nov.?, which previously was only known from Colhuehuapian sediments (Early Miocene) from Sarmiento Formation, Trelew Member of Chubut Province, Argentina (Arnal et al., 2014).

In summary, 20 mammal species present in the upper levels of RSC (SBB) are absent in BB. Nineteen of this group of 20 distinct SBB species representing in a younger time interval are also found in older Atlantic coastal Santacrucian faunas. In contrast, despite being more similar in age to the Atlantic coastal localities, the fauna of the BB stratigraphic interval is less similar to the Atlantic coastal faunas of similar age. Several obvious possibilities present themselves to explain these differences. First, it could be that the formal difference might be accounted for by sampling error -different amounts of collecting effort between BB and SBB - so that if we more intensely collected at BB we would document the "missing" taxa. This possibility is suggested by the fact that the mammal specimens collected in BB (540) represent $42 \%$ of the specimens recovered in SBB (1267). Despite this difference, the number of specimens from BB identified at specific level (307) represents $47 \%$ of the specimens from SBB identified at the same level. It may be the case that what it is relevant is the difference in relative abundance of specimens rather than the size of the sample. In SBB, three species absent in BB represent $24 \%$ (156) of the specimens collected: Prolagostomus pusillus Ameghino, 1887a, Pliolagostomus notatus Ameghino, 1887a (Arnal et al., 2019: tab. 2), and Pachyrukhos moyani Ameghino, 1885 (Fernández and Muñoz, 2019: appendix 2). A fourth 


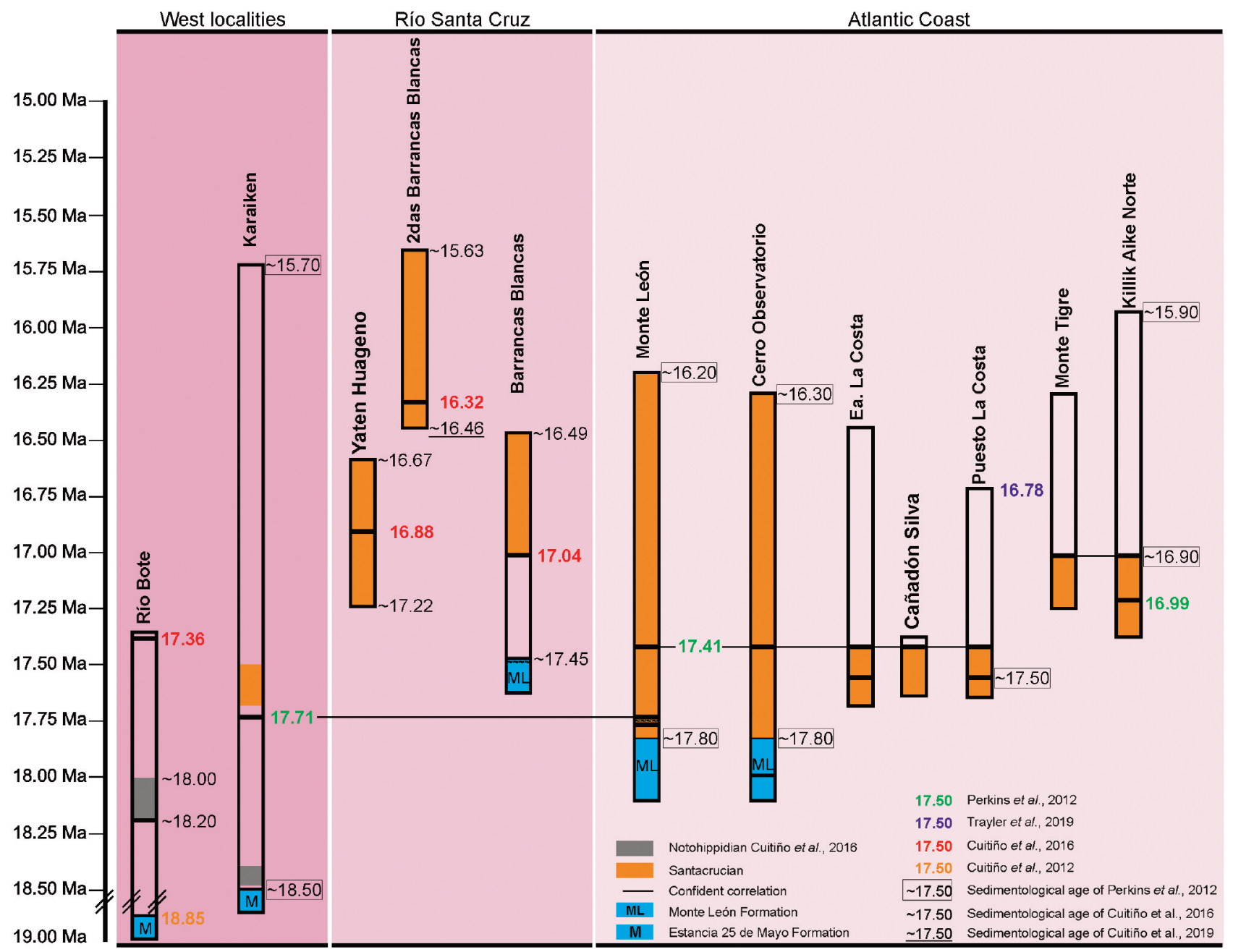

Figure 4. Chronostratigraphic correlation scheme for the Santacrucian sections of the Santa Cruz Formation at the Río Santa Cruz, Río Bote, and Atlantic Coast mentioned in this study The vertical extension of the columns is calculated assuming an average sedimentation rate of $150 \mathrm{~m} / \mathrm{Ma}$ (Cuitiño et al., 2016, 2019b), represents time (Ma). Lithostratigraphic units are indicated in capital letters, excepting the Santa Cruz Formation (modified from Cuitiño et al., 2016).

species, Protypotherium australe Ameghino, 1887b, is represented in SBB by 60 specimens and by only one specimen in BB (Fernández and Muñoz, 2019: appendix 2). The four species mentioned represent a third (216) of the specimens of SBB. If we exclude from the analysis these four species the number of specimens identified at a specific level in BB (306) would represent $70 \%$ of those of SBB (431). Thus, it is possible that the differences in the number of specimens between both localities are more related to the different abundances of certain species than to a different sampling effort.

Presence or absence of species is not the only phe- nomenon that supports this view. There also are examples where the local faunas show presence of the same species but extreme variation in its relative abundance (see above). Arnal et al. (2019: tab. 2) provide notable examples for this among chinchilloids. For example, Perimys is relatively common at BB and SBB, but at SBB the largest species, Perimys onustus, is very common (23 specimens) and a smaller species, $P$. erutus, is uncommon (three specimen), whereas at $\mathrm{BB}, P$. onustus is represented by only a single specimen, and the smaller species by twelve: $P$. erutus (11 specimens) and $P$. incavatus (one specimen).

Another possibility is that there could be different sedi- 
mentological regimes (more coarse or more fine-grained sediment, differential predominance of channels versus overbank deposits, etc.) leading to differential accumulation of the species comprising the vertebrate death assemblages. But the geologic studies of Cuitiño et al. (2019b) reveal no obvious sedimentological differences between BB and SBB levels.

Finally, perhaps the variations among the localities are mediated by differences in the environment that could affect local distribution of Santacrucian species. This third option is the one we favor based on the present evidence. To elaborate, we conceive of a relatively stable regional Santacrucian fauna of longstanding inhabiting a mosaic environment with scrublands or grasslands and riverine forests as that proposed by Kay et al. (2012) between 17.5 Ma and $~ 15.5 \mathrm{Ma}$. Under this hypothesis, variation in the presence or absence of species within this regional fauna could be accounted for directly by local variation in climatic factors, such as rainfall, temperature, elevation, or distance from a paleo-coastline. Or climatic variations could have indirect effects, casting an influence on overall vegetational composition. In this general scenario of proximate coexistence of different floral communities, relatively minor climatic variations would imply the recession of one plant community and the expansion of the other, each with its accompanying fauna. In this way, a species would be contemporaneously present in a particular part of the landscape but absent in another part, as seems to be the case.

\section{Biozones}

Tauber (1997a,b, 1999) identified two sedimentary units in the coastal SCF between the Río Coyle and the Río Gallegos: a lower Estancia La Costa Member and an upper Estancia La Angelina Member. He identified 22 Fossiliferous Levels $(F L)$ in the sequence. Based on his own stratigraphic work, fossil collections and taxonomic identifications, Tauber (1997a) proposed two taxon-range biozones for the Estancia La Costa Member. The lower Protypotherium attenuatum biozone comprised of FLs 3 to 7 was based on the exclusive presence of this homonymous typothere. The upper Protypotherium australe biozone (FL 8 to 10) was based on the exclusive presence of that taxon in the upper levels. Tauber (1997a, p. 423) noted that in order to formally define these biozones it would be necessary to confirm its regional applicability with a more complete paleontological record. Later, Krapovickas et al. (2008) extended the P. attenuatum zone to encompass FL 1 to 7 and the $P$. australe zone from FL 5.3 to 10. They formulated a new biozone restricted to the overlap of the two species (FL 5.3 to 7), which was referred as $P$. attenuatum- $P$. australe zone. However, Kay et al. (2012) recognized the presence of $P$. australe at Estancia La Costa (FL 1 to 4 of Tauber, 1997a). Krapovickas et al. (2008, p. 1020) acknowledged that it was necessary to establish the geographic distribution of the Protypotherium spp. with more certainty in order to confirm their real value for defining biozones. Tauber et al. (2008), in a brief report of the SCF in the $\mathrm{RSC}$, recognized around thirteen genera of fossil mammals collected in Ea. El Refugio, Ea. Cordón Alto, and Ea. Rincón Grande (three of the estancias along the RSC mentioned above). Among these taxa, Tauber et al. (2008) only provided the geographical position of Protypotherium attenuatum (YH) and Protypotherium australe (SBB), possibly due to its biostratigraphic importance.

The temporal distribution that we recorded for these species along the RSC makes arguable that these biozones should be set aside. The two Protypotherium species overlap extensively, with $P$. australe found at both levels: the BB levels between $\sim 16.80$ and $16.57 \mathrm{Ma}$, and SBB levels between $\sim 16.44$ and 16.02 Ma (Fig. 5). Likewise, P. attenuatum is recorded in both BB and SBB. The overlapping temporal distribution of $P$. australe and $P$. attenuatum shows that it is not possible to define biozones based exclusively on one of these taxa. Thus, it is clear that the definition of biozones requires a greater knowledge of the spatio-temporal distribution of taxa that could define them.

\section{The type locality for the Santacrucian fauna}

As mentioned above, Marshall et al. $(1983,1986)$ proposed that the Monte León local fauna should be designated as the nominal type area of the Santacrucian fauna. Instead, we propose that the exposures along the RSC should be considered as a type area for the Santacrucian. Beyond the complex situation regarding the Ameghino collection and the scant and sometimes ambiguous information associated with its specimens, there is no doubt that the initial concept of this fauna formulated by Ameghino in 1889 


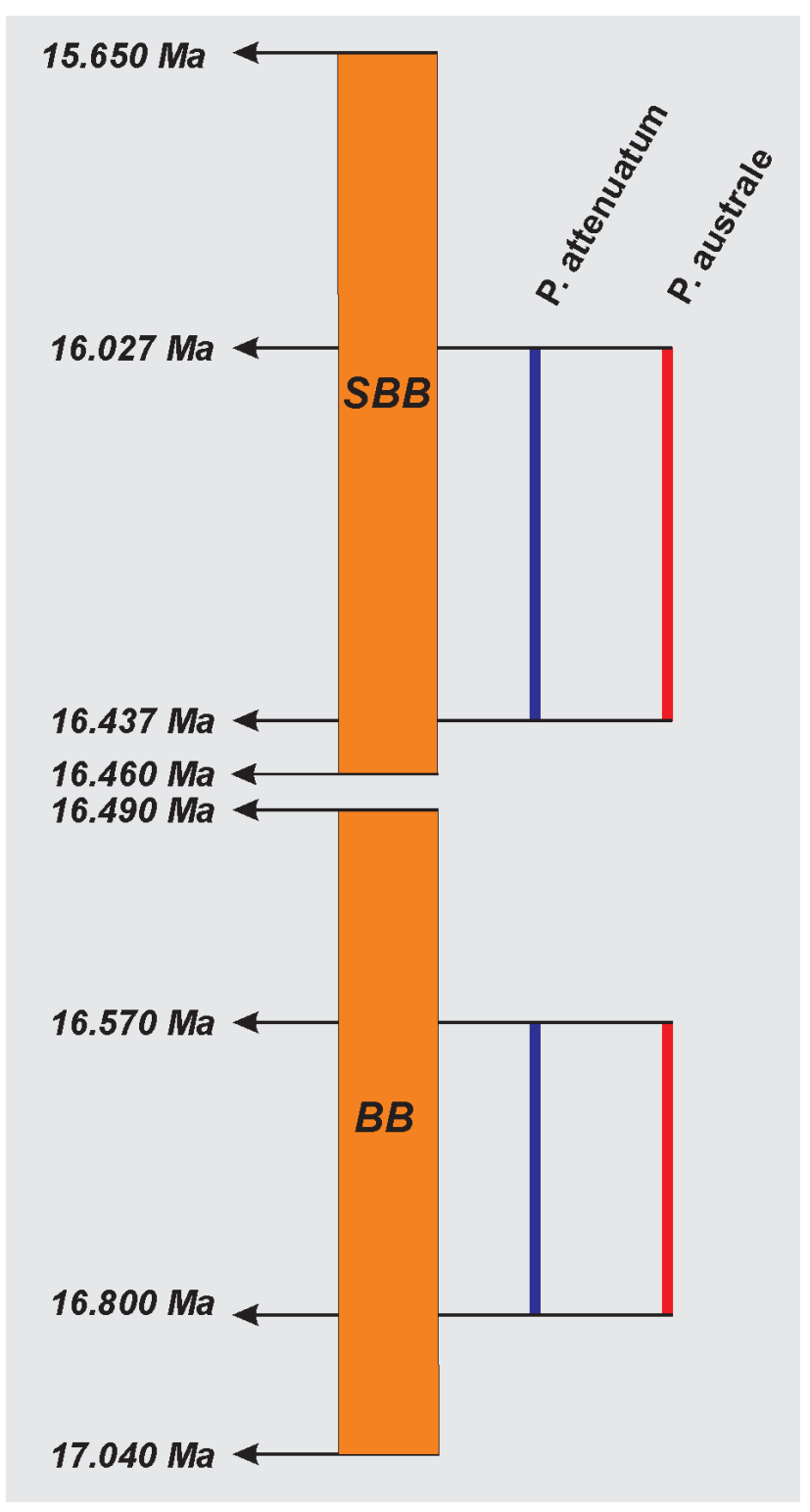

Figure 5. Temporal distribution of Protypotherium attenuatum (blue) and $P$. australe (red) at BB and SBB. The specimen of $P$. australe from BB was collected at Estancia Santa Lucía Section which estimated time span between 16.8 to $16.57 \mathrm{Ma}$ (Cuitiño et al., 2019b).

based on the species collected in the RSC in 1887 and before any substantial collections were made from Monte León or other coastal areas. There are pertinent reasons beyond the purely historical ones. As originally mentioned by Carlos Ameghino (in Rusconi, 1965), BB exposes the transitional contact of the SCF with the underlying marine Monte León Formacion. At SBB, the youngest fossil levels of the entire SCF are in stratigraphic and chronological continuity with those of BB. Thus, the RSC composite section spans a greater temporal interval than that on the coast. For these reasons, we propose that RSC exposures should be considered as the type locality for the Santacrucian fauna.

\section{CONCLUSIONS}

The historical analysis of the $19^{\text {th }}$ century fossil collections from the SCF along the RSC and its tributary Río Bote clarify some of the confusion in the older literature as it relates to the composition of the Santacrucian fauna as distinct from a supposedly older Notohippidian mammalian fauna in the West at Karaiken, and younger Santacrucian from the RSC and the Atlantic coast (Ameghino, 1889). Certainly, several species before considered as exclusive for the Notohippidian have been recorded elsewhere, in levels considered as typically Santacrucian. In this sense, only new faunal lists based on specimens collected in new fieldwork will help to elucidate the real distinction of a Notohippidian fauna and produce an accurate understanding of the taxonomic richness of SCF along the RSC and the West of the Province of Santa Cruz.

The new collection of more than 1900 specimens reported in this volume (Fernicola et al., 2019b) updated the list of SCF mammalian species recorded along the RSC. The new collection rivals the old one in terms of numbers of specimens. Combining the old and new collections lists, including new first reports, the taxonomic richness is of 95 taxa, not the 110 as Ameghino (1887a) originally listed.

The taxonomic richness in the three localities along the RSC is substantially different: 47 species from BB, 60 species from SBB and nine species from $\mathrm{YH}$. The poor sample from YH supports Onelli's contra Carlos Ameghino's view about the fossil abundance of the locality and prevented us to analyze it further.

There are also considerable differences in the faunal composition between BB and SBB. The two share 31 species, of which six are present only at BB (two rodents, one litoptern, one notoungulate, and two cingulates) and 20 only at SBB (10 rodents, two litopterns, two notoungulates, three sloths, and three methaterians).

The great majority of fossil mammal species recorded in the new collections at the RSC (more than $85 \%$ ) are also found at Atlantic coastal localities. In spite of BB ( 17.05 to 
16.49 Ma) being closer in age to the older Atlantic coastal levels the SCF between Monte León and Río Gallegos, and SBB fossils being younger ( 16.46 to $\sim 15.65 \mathrm{Ma})$ than the Atlantic coastal levels, the greatest similarity is between SBB and the coast.

We interpret that faunal differences among the localities largely to result from local variation in climatic factors, such as rainfall, temperature, elevation, or distance from a paleo-coastline. Also, climatic variations could have indirect effects, casting an influence on overall vegetational composition. In this general scenario of proximate coexistence of different floral communities, relatively minor climatic variations would imply the retreat of one plant community and the expansion of another and its accompanying fauna. In this way, certain species would be contemporaneously present in a particular part of the landscape but absent or rare in another part, as seems to be the case.

We have revised and challenged the validity of proposed Santacrucian biostratigraphic units (biozones) based on distributions of the typotheres Protypotherium australe and $P$. attenuatum within the Santacrucian fauna as a whole by Tauber (1997a) and Krapovickas et al. (2008). After reevaluation of the stratigraphic distribution of these species, we argue that the Santacrucian is a unified fauna that shows regional and temporal differences that arise from local variation in climatic conditions and propose that these biozones be set aside.

Finally, contrary to Marshall et al. (1983, 1986), who considered that the exposures of the SCF at Monte León be designated as the nominal type area of the formation and the Santacrucian fauna, we propose to return to Ameghino's concept that the exposures along the RSC be considered as a type area. This is for two reasons. First, the South side of the RSC was the region that formed the original basis for Ameghino's concept. Second, collectively the richly fossiliferous faunal assemblages at BB and SBB span the whole known temporal range of the Santacrucian fauna: BB exposes the transitional contact of the SCF with the underIying marine Monte León Formation, and the temporally overlapping SBB has the youngest fossil levels of the entire SCF.

130 years after the first paleontological expedition to the RSC, its exposures and fossils remain crucial for under- standing the successions of mammalian faunas in the Patagonia Cenozoic. They also constitute the most important record of high latitude terrestrial paleoenvironments, paleoclimates, and paleoecosystems in the Southern Hemisphere during Early and Middle Miocene.

\section{ACKNOWLEDGEMENTS}

We thank the collection managers of the Vertebrate Paleontology collections at MLP (M. Reguero), and MACN (L. Chornogubsky and M. Ezcurra), and the Dirección de Patrimonio, Secretaría de Cultura de Estado (Province of Santa Cruz), and Museo Regional Provincial P.M.J. Molina.We thank especially L. Acosta, L. Chornogubsky, L. González, V. Krapovickas, S. Hernández del Pino, N.A. Muñoz, A. Racco, and J. Spradley for their collaboration during field work. Also, we acknowledge the work of the two anonymous reviewers and the editor of PE-APA for their comments and corrections. This is a contribution to the projects PIP-CONICET 00781, UNLP 11/N867, PICT 2013-0389 and 2017-1081, National Science Foundation grants 0851272 and 1348259, and National Geographic Society 9167-12.

\section{REFERENCES}

Ameghino, F. 1885. Nuevos restos de mamíferos fósiles oligocenos, recogidos por el profesor Pedro Scalabrini y pertenecientes al Museo Provincial de la Ciudad del Paraná. Boletín de la Academia Nacional de Ciencias de Córdoba 8: 5-207.

Ameghino, F. 1887a. Enumeración sistemática de las especies de mamíferos fósiles coleccionados por Carlos Ameghino en los terrenos eocenos de Patagonia Austral y depositados en el Museo de La Plata. Boletín del Museo de La Plata 1-26.

Ameghino, F. 1887b. Observaciones generales sobre el orden de mamíferos extinguidos sub-americanos llamados Toxodontes (Toxodontia) y sinopsis de los géneros y especies hasta ahora conocidos. Anales del Museo de La Plata 1: 1-66.

Ameghino, F. 1889. Contribución al conocimiento de los mamíferos fósiles de la República Argentina. Actas de la Academia Nacional de Ciencias 6: 1-1027.

Ameghino, F. 1891. Nuevos restos de mamíferos fósiles descubiertos por Carlos Ameghino en el Eoceno inferior de la Patagonia austral. Especies nuevas, adiciones y correcciones. Revista Argentina de Historia Natural 1: 289-328.

Ameghino, F. 1900-1902. L'âge des formations sédimentaires de Patagonie. Anales de la Sociedad Científica Argentina 50: 109130; 145-165; 209-229; 51: 20-39; 52: 65-91; 189-197; 244-250; 54: 161-180; 220-249; 283-342.

Ameghino, F. 1906. Les formations sédimentaires du Créetacé Superieur et du Tertaire de Patagonie avec un parallele entre leurs faunes mammalogiques et celles de l'ancien continent. Anales del Museo Nacional de Buenos Aires 15: 1-568.

Arnal, M. 2012. [Sistemática, filogenia e historia evolutiva de roedores Octodontoidea (Caviomorpha, Hystricognathi) del Oligoceno tardioMioceno medio vinculados al origen de la familia Octodontidae. Tesis doctoral, Facultad de Ciencias Naturales y Museo, Universidad Nacional de La Plata, La Plata, 317 p. Unpublished.].

Arnal, M., Kramarz, A.G., Vucetich, M.G., and Vieytes, C.E. 2014. A new Early Miocene octodontoid rodent (Hystricognathi, Caviomorpha) from Patagonia (Argentina) and a reassessment of the early evolution of Octodontoidea. Journal of Vertebrate Paleontology 34: 397-406.

Arnal, M., Pérez, M.E., and Deschamps, C.M. 2019. Revision of the 
Miocene Caviomorph rodents from the Río Santa Cruz (Argentinean Patagonia). In: J.C. Fernicola, M.S. Bargo, S.F. Vizcaíno, and R.F. Kay (Eds.), Early-Middle Miocene Paleontology in the Río Santa Cruz, Southern Patagonia, Argentina. 130 years since Ameghino, 1887. Publicación Electrónica de la Asociación Paleontológica Argentina 19: 193-229.

Arnal, M., and Vucetich, M.G. 2015. Revision of the fossil rodent Acaremys Ameghino, 1887 (Hystricognathi, Octodontoidea, Acaremyidae) from the Miocene of Patagonia (Argentina) and the description of a new acaremyid. Historical Biology 27: 4259.

Arnal, M., Vucetich, M.G., Croft, D.A., Bargo, M.S., Fernicola, J.C., and Vizcaíno, S.F. 2017. Systematic revision and evolutionary history of Acarechimys Patterson in Kraglievich, 1965 (Rodentia, Caviomorpha, Octodontoidea). Ameghiniana 54: 307-330.

Bargo, M.S., De luliis R., and Toledo, N. 2019. Early Miocene sloths (Xenarthra, Folivora) from the Río Santa Cruz valley (Southern Patagonia, Argentina). Ameghino, 1887 revisited. In: J.C. Fernicola, M.S. Bargo, S.F. Vizcaíno, and R.F. Kay (Eds.), Early-Middle Miocene Paleontology in the Rio Santa Cruz, Southern Patagonia, Argentina. 130 years since Ameghino, 1887. Publicación Electrónica de la Asociación Paleontológica Argentina 19: 102-137.

Brinkman, P.D., and Vizcaíno, S.F. 2014. Clemente Onelli's sketch map and his first-hand, retrospective account of an early fossilhunting expedition along the Río Santa Cruz, southern Patagonia, 1888-1889. Society for the Bibliography of Natural History; Archives of natural history 41: 326-337.

Cabrera, A. 1927. Datos para el conocimiento de los Dasiuroideos fósiles argentinos. Revista del Museo de La Plata 30: 271-315.

Cobos, J.C., Rodríguez, M.F., and Panza, J.L. 2014. Hoja Geológica 5172-II, Paso Río Bote, Provincia de Santa Cruz. Boletín del Instituto de Geología y Recursos Minerales, Servicio Geológico Minero Argentino 405: 1-99.

Cuitiño, J.I., Fernicola, J.C., Kohn, M., Trayler, R., Naipauer, M., Bargo, M.S., Kay, R.F., and Vizcaíno, S.F. 2016. U-Pb geochronology of the Santa Cruz Formation (early Miocene) at the Río Bote and Río Santa Cruz (southernmost Patagonia, Argentina): implications for the correlation of fossil vertebrate localities. Journal of South America Earth Sciences 70: 198-210.

Cuitiño, J.I. Fernicola, J.C., Raigemborn, M.S., and Krapovickas, V. 2019b. Stratigraphy and depositional environments of the Santa Cruz Formation (Early-Middle Miocene) along the Río Santa Cruz, Southern Patagonia, Argentina. In: J.C. Fernicola, M.S. Bargo, S.F. Vizcaíno, and R.F. Kay (Eds.), Early-Middle Miocene Paleontology in the Río Santa Cruz, Southern Patagonia, Argentina. 130 years since Ameghino, 1887. Publicación Electrónica de la Asociación Paleontológica Argentina 19: 14-33.

Cuitiño, J.I., and Scasso, R.A. 2010. Sedimentología y paleoambientes del Patagoniano y su transición a la Formación Santa Cruz al sur del Lago Argentino, Patagonia Austral. Revista de la Asociación Geológica Argentina 66: 406-417.

Cuitiño, J.I., Vizcaíno, S.F., Bargo, M.S., and Aramendía, I. 2019a. Sedimentology and fossil vertebrates of the Santa Cruz Formation (early Miocene) in Lago Posadas, southwestern Patagonia, Argentina. Andean Geology 46: 383-420.

Chornogubsky, L., Abello, M.A., and Barmak, G. 2019. The Metatheria from the Río Santa Cruz (Santa Cruz Formation, Early-Middle Miocene, Argentina): history and new findings. In: J.C. Fernicola, M.S. Bargo, S.F. Vizcaíno, and R.F. Kay (Eds.), Early-Middle Miocene Paleontology in the Río Santa Cruz, Southern Patagonia, Argentina. 130 years since Ameghino, 1887. Publicación Electrónica de la Asociación Paleontológica Argentina 19: 62-84.
Dalziel, I.W.D., De Wit, M.J., and Palmer, K.F. 1974. A fossil marginal basin in the southern Andes. Nature 250: 291-294.

Fernández, M., and Muñoz, N.A. 2019. Notoungulata and Astrapotheria (Mammalia, Meridiungulata) of the Santa Cruz Formation (Early-Middle Miocene) along the Río Santa Cruz, Argentine Patagonia. In: J.C. Fernicola, M.S. Bargo, S.F. Vizcaíno, and R.F. Kay (Eds.), Early-Middle Miocene Paleontology in the Río Santa Cruz, Southern Patagonia, Argentina. 130 years since Ameghino, 1887. Publicación Electrónica de la Asociación Paleontológica Argentina 19: 138-169.

Fernicola, J.C. 2011a. 1886-1888: Ascenso, auge y caída de la sociedad entre Florentino Ameghino y Francisco P. Moreno. Publicación Especial de la Asociación Paleontológica Argentina 12: 35-49.

Fernicola, J.C. 2011b. Implicancias del conflicto Ameghino-Moreno sobre la colección de mamíferos fósiles realizada por Carlos Ameghino en su primera exploración al río Santa Cruz, Argentina. Revista del Museo Argentino de Ciencias Naturales, n.s. 13: 41-57.

Fernicola, J.C., Bargo, M.S., Vizcaíno, S.F., and Kay, R.F. 2019a. Historical background for a revision of the paleontology of the Santa Cruz Formation (Early-Middle Miocene) along the Río Santa Cruz, Patagonia, Argentina. In: J.C. Fernicola, M.S. Bargo, S.F. Vizcaíno, and R.F. Kay (Eds.), Early-Middle Miocene Paleontology in the Río Santa Cruz, Southern Patagonia, Argentina. 130 years since Ameghino, 1887. Publicación Electrónica de la Asociación Paleontológica Argentina 19: 1-13.

Fernicola, J.C., Bargo, M.S., Vizcaíno, S.F., and Kay R.F. (Eds.) $2019 \mathrm{~b}$. Early-Middle Miocene Paleontology in the Río Santa Cruz, Southern Patagonia, Argentina. 130 years since Ameghino, 1887. Publicación Electrónica de la Asociación Paleontológica Argentina 19:.

Fernicola, J.C., Cuitiño, J.I., Vizcaíno, S.F., Bargo, M.S., and Kay, R.F. 2014. Fossil localities of the Santa Cruz Formation (early Miocene, Patagonia, Argentina) prospected by Carlos Ameghino in 1887 revisited and the location of the Notohippidian. Journal of South America Earth Sciences 52: 9-107.

Fernicola, J.C., and Vizcaíno, S.F. 2019. Cingulates (Mammalia, Xenarthra) of the Santa Cruz Formation (Early-Middle Miocene,) from the Río Santa Cruz, Argentine Patagonia. In: J.C. Fernicola, M.S. Bargo, S.F. Vizcaíno, and R.F. Kay (Eds.), Early-Middle Miocene Paleontology in the Rio Santa Cruz, Southern Patagonia, Argentina. 130 years since Ameghino, 1887. Publicación Electrónica de la Asociación Paleontológica Argentina 19: 85-101.

Fleagle, J.G., Perkins, M.E., Heizler, M.T., Nash, B., Bown, T.M., Tauber, A.A., Dozo, M.T., Tejedor, M.F., 2012. Absolute and relative ages of fossil localities in the Santa Cruz and Pinturas formations. In: S.F. Vizcaíno, R.F. Kay, and M.S. Bargo (Eds.), Early Miocene Paleobiology in Patagonia: High-Latitude Paleocommunities of the Santa Cruz Formation. Cambridge University Press, Cambridge, p. 41-58.

Fosdick, J.C., Grove, M., Hourigan, J.K., and Calderón, M. 2013. Retroarc deformation and exhumation near the end of the Andes, southern Patagonia. Earth and Planetary Science Letters 361: 504-517.

Ghiglione, M.C., Ramos, V.A., Cuitiño, J.I., and Varberón, V. 2016. Growth of the Southern Patagonian Andes $\left(46-53^{\circ} \mathrm{S}\right)$ and their Relation to Subduction Processes. In: A. Folguera, M. Naipauer, L. Sagripanti, M. Ghiglione, D. Orts, and L. Giambiagi (Eds.), Growth of the Southern Andes. Springer Earth System Sciences, Springer International Publishing, Switzerland, p. 201-240. Doi: 10.1007/978-3-319-23060-3.

Kay, R.F., and Perry, J.M.G. 2019. New primates from the valleys of 
the Río Santa Cruz and Río Bote (Early-Middle Miocene), Santa Cruz Province, Argentina. In: J.C. Fernicola, M.S. Bargo, S.F. Vizcaíno, and R.F. Kay (Eds.), Early-Middle Miocene Paleontology in the Río Santa Cruz, Southern Patagonia, Argentina. 130 years since Ameghino, 1887. Publicación Electrónica de la Asociación Paleontológica Argentina 19: 230-238.

Kay, R.F., Vizcaíno, S.F., and Bargo, M.S. 2012. A review of the paleoenvironment and paleoecology of the Miocene Santa Cruz Formation. In: S.F. Vizcaíno, R.F. Kay, and M.S. Bargo (Eds.), Early Miocene Paleobiology in Patagonia: High-Latitude Paleocommunities of the Santa Cruz Formation. Cambridge University Press, Cambridge, p. 331-365.

Krapovickas, J., Tauber, A.A., and Rodríguez, P.E. 2008. Nuevo registro de Protypotherium australe Ameghino, 1887: implicancias bioestratigráficas en la Formación Santa Cruz. $17^{\circ}$ Congreso Geológico Argentino (San Salvador de Jujuy), Actas: 1020-1021.

Marshall, L.G., Drake, R.E., Curtis, G.H., Butler, R.F., Flanagan, K.M., Naeser, C.W. 1986. Geochronology of Type Santacrucian (Middle Tertiary) Land Mammal Age, Patagonia, Argentina. The Journal of Geology 94: 449-457.

Marshall, L.G., Hoffstetter, R., and Pascual, R. 1983. Mammals and stratigraphy: Geochronology of the continental mammalbearing Tertiary of South America. Paleovertebrata, Mémoire Extraordinaire 1-93.

Marshall, L.G., and Pascual, R. 1977. Nuevos marsupiales Caenolestidae del "Piso Notohipidense" (SW de Santa Cruz, Patagonia) de Ameghino. Sus aportaciones a la cronología y evolución de las comunidades de mamíferos sudamericanos. Publicación del Museo Municipal de Ciencias Naturales de Mar del Plata "Lorenzo Scaglia" 2: 91-22.

Mercerat, A. 1891. Notas sobre la paleontología de la República Argentina. II. Sinopsis de la familia de los Proxotodontidae conservados en el Museo de La Plata (Eoceno de Patagonia). Revista del Museo de La Plata 1: 381-444.

Moreno, F.P. 1879. Viaje a la Patagonia Austral, emprendido bajo los auspicios del gobierno nacional, 1876-1877. Imprenta de La Nación, Buenos Aires, 460 p.

Parras, A.M., and Cuitiño, J.I. 2018. The stratigraphic and paleoenvironmental significance of the regressive Monte Observación Member, early Miocene of the Austral Basin, Patagonia. Latin American Journal of Sedimentology and Basin Analysis 25: 25-47.

Pascual, R., Ortega Hinojosa, E.J., Gondar, D., and Tonni, E.P. 1965. Las edades del Cenozoico mamalífero de la Argentina, con especial atenci6n a aquellas del territorio Bonaerense. Anales de la Comisión de Investigaciones Científicas 6: 165-193.

Pérez, M.E. 2010. [Sistemática, ecología y bioestratigrafía de Eocardiidae (Rodentia, Hystricognathi, Cavioidea) del Mioceno temprano y medio de Patagonia. Tesis Doctoral, Facultad de Ciencias Naturales y Museo, Universidad Nacional de La Plata, La Plata, 385 p. Unpublished.].

Perkins, M.E., Fleagle, J.G., Heizler, M.T., Nash, B., Bown, T.M., Tauber, A.A., and Dozo, M.T. 2012. Tephrochronology of the Miocene Santa Cruz and Pinturas Formations, Argentina. In: S.F. Vizcaíno, R.F. Kay, and M.S. Bargo (Eds.), Early Miocene Paleobiology in Patagonia: High-Latitude Paleocommunities of the Santa Cruz Formation. Cambridge University Press, Cambridge, p. 2340.

Racco, A., Fernicola, J.C., Bargo, M.S., Vizcaíno, S.F., and De luliis, G. 2018. On the type of Schismotherium fractum Ameghino, 1887 (Xenarthra, Folivora, Megatherioidea) from the Early Miocene Santa Cruz Formation (Santa Cruz province, Argentina). Ameghiniana 55: 117-125.
Raigemborn, M.S., Krapovickas, V., Zucol, A.F., Zapata, L., Beilinson, E., Toledo, N., Perry, J., Lizzoli, S., Martegani, L., Tineo, D., and Passeggi, E. 2018. Paleosols and related soil-biota of the early Miocene Santa Cruz Formation (Austral-Magallanes Basin, Argentina): a multidisciplinary approach to reconstructing ancient terrestrial landscapes. Latin American Journal of Sedimentology and Basin Analysis 25: 117-148.

Rasia, L.L. 2016. [Los Chinchillidae (Rodentia, Caviomorpha) fósiles de la República Argentina: sistemática, historia evolutiva y biogeográfica, significado bioestratigráfico y paleoambiental. Tesis Doctoral, Facultad de Ciencias Naturales y Museo, Universidad Nacional de La Plata, La Plata, 246 p. Unpublished.].

Rusconi, C. 1965. Carlos Ameghino. Rasgos de su vida y obra. Revista del Museo de Historia Natural de Mendoza 17: 1-160.

Sacomani, L.E., and Panza, J.L. 2011. Hojas Geológicas 5169-I y 5169-II, Puerto Coig y Puerto Santa Cruz, Provincia de Santa Cruz. Boletín Instituto de Geología y Recursos Minerales, Servicio Geológico Minero Argentino 392: 1-133.

Schmidt, G.I., Hernández del Pino, S., Muñoz, N.A., and Fernández, M. 2019. Litopterna (Mammalia) from the Santa Cruz Formation (Early-Middle Miocene) at Río Santa Cruz, Southern Argentina. In: J.C. Fernicola, M.S. Bargo, S.F. Vizcaíno, and R.F. Kay (Eds.), Early-Middle Miocene Paleontology in the Río Santa Cruz, Southern Patagonia, Argentina. 130 years since Ameghino, 1887. Publicación Electrónica de la Asociación Paleontológica Argentina 19: 170-192.

Simpson, G.G. 1940. Review of the Mammal-Bearing Tertiary of South America. Proceedings of the American Philosophical Society 83: 649-709.

Sinclair, W.J. 1909. Mammalia of the Santa Cruz beds. Part I. Typotheria. In: W.B. Scott (Ed.), Reports of the Princeton University Expeditions to Patagonia, 1896-1899. Princeton, Princeton University, New Jersey, p. 1-110.

Scott, W.B. 1903. Mammalia of the Santa Cruz beds. Part I. Edentata. In: Scott W.B. (Ed.), Reports of the Princeton University Expeditions to Patagonia 1896-1899. Vol. 5, Paleontology 2, Princeton: Princeton University Press, New Jersey, p. 1-226.

Soria, M.F. 2001. Los Proterotheriidae (Mammalia, Litopterna): sistemática, origen y filogenia. Monografías del Museo Argentino de Ciencias Naturales "Bernardino Rivadavia" 1: 1-167.

Tauber, A.A. 1996. Los representantes del género Protypotherium (Mammalia, Notoungulata, Interatheridae) del Mioceno Temprano del sudoeste de la Provincia de Santa Cruz, República Argentina. Academia Nacional de Ciencias 95: 1-29.

Tauber, A.A. 1997a. Biostratigraphy of the Santa Cruz Formation (Lower Miocene) in southeastern Patagonia. Ameghiniana 34: 413-426.

Tauber, A.A. 1997b. Palaeoecology of the Santa Cruz Formation (Lower Miocene) in the southeast border of Patagonia. Ameghiniana 34: 517-529.

Tauber, A.A. 1999. Los vertebrados de la Formación Santa cruz (Mioceno inferior-medio) en el extremo sureste de la Patagonia y su significado paleoecológico. Revista Española de Paleontología 14: 173-182.

Tauber, A.A., Palacios, M.E., Krapovickas, J., and Rodríguez, P. 2008. La Formación Santa Cruz (Mioceno temprano-medio) en la mitad occidental del Río Santa Cruz, Patagonia, Argentina. $17^{\circ}$ Congreso Geológico Argentino (San Salvador de Jujuy), Actas: 1500-1501.

Tejedor, M.F., Tauber, A.A., Rosenberger, A.L., Swisher, C.C., and Palacios, M.E. 2006. New primate genus from the Miocene of Argentina. Proceedings of the National Academy of Sciences 103: 5437-5441. 
Trayler, R.B. Schmitz, D.M., Cuitiño, J.I., Kohn, M., Bargo, M.S., Kay, R.F., Strömberg, C.A.E., and Vizcaíno, S.F. 2019. An improved approach to age-modeling in deep time: Implications for the Santa Cruz Formation, Argentina. GSA Bulletin https://doi.org/10.1130/ B35203.1

Vizcaíno, S.F. 2011. Cartas para Florentino desde la Patagonia. Crónica de la correspondencia édita entre los hermanos Ameghino (1887-1902). In: J.C. Fernicola, A. Prieto, and D. Lazo (Eds.), Vida y obra de Florentino Ameghino, Publicación Especial de la Asociación Paleontológica Argentina Nº 12: 51-67.

Vizcaíno, S.F., Bargo, M.S., and Fernicola, J.C. 2013. Expediciones paleontológicas durante los siglos XIX y XX A la Formación Santa Cruz (Mioceno Inferior, Patagonia) y destino de los fósiles. $3^{\circ}$ Congreso Argentino de Historia de la Geología (Salta), Actas: 231-246.

Vizcaíno, S.F., Kay, R.F., and Bargo, M.S. 2012a. Background for a paleoecological study of the Santa Cruz Formation (late Early
Miocene) on the Atlantic Coast of Patagonia. In: S.F. Vizcaíno, R.F. Kay, and M.S. Bargo (Eds.), Early Miocene Paleobiology in Patagonia: high-latitude paleocommunities of the Santa Cruz Formation. Cambridge University Press, Cambridge, p. 1-22.

Vizcaíno, S.F., Kay, R.F., and Bargo, M.S. 2012b. Early Miocene Paleobiology in Patagonia: high-latitude paleocommunities of the Santa Cruz Formation. Cambridge University Press, Cambridge, 370 p.

Doi: 10.5710/PEAPA.01.11.2019.309

Recibido: 28 de septiembre 2019

Aceptado: 1 de noviembre 2019

Appendix 1. List of the mammalian taxa recorded in the Río Santa Cruz based on the new specimens (MPM-PV) described in the articles of this volume (Fernicola et al., 2019b). It includes 64 species (six at genus of uncertain species and a Planopinae indet.).

\section{METATHERIA}

SPARASSODONTA

Hathlyacinidae

Cladosictis patagonica Ameghino, 1887a

Sipalocyon gracilis Ameghino, 1887a

Borhyaenidae

Perathereutes pungens Ameghino, 1891

PAUCITUBERCULATA

Borhyaena tuberata Ameghino, 1887a

Abderitidae

Palaeothentidae

Abderites meridionalis Ameghino, 1887a

Acdestis oweni Ameghino, 1887a

Palaeothentes lemoinei Ameghino, 1887a

Palaeothentes intermedius Ameghino, 1887a

MICROBIOTHERIA

Palaeothentes minutus Ameghino, 1887a

Microbiotheriidae

XENARTHRA

Microbiotherium tehuelchum Ameghino, 1887a

FOLIVORA

Megatherioidea

Hapalops cf. elongatus Ameghino, 1891

Schismotherium cf. fractum Ameghino, 1887a

Xyophorus atlanticus Ameghino, 1891

Megatheriidae

Planopinae indet.

Mylodontoidea

Mylodontidae

Nematherium longirostris Ameghino, 1891

CINGULATA

Peltephilidae

"Dasypodidae"

Peltephilus pumilus Ameghino, 1887a

Stegotherium tessellatum Ameghino, 1887a

Prozaedyus proximus (Ameghino, 1887a)

Stenotatus patagonicus (Ameghino, 1887a)

Propalaehoplophoridae

Proeutatus oenophorus (Ameghino, 1887a)

Cochlops muricatus Ameghino, 1889

Eucinepeltus sp. 
ASTRAPOTHERIA

Astrapotheriidae

NOTOUNGULATA

TOXODONTIA

Homalodotheriidae

Toxodontidae

TYPOTHERIA

Hegetotheriidae

Interatheriidae

LITOPTERNA

Proterotheriidae

Macraucheniidae

\section{RODENTIA}

CAVIOMORPHA

Octodontoidea

Acaremyidae

Erethizontoidea

Erethizontidae

Cavioidea

Chinchilloidea

Chinchillidae

Neoepiblemidae

Dinomyidae

PRIMATES

Homunculidae
Astrapotherium magnum (Owen, 1853)

Homalodotherium sp.

Nesodon imbricatus Owen, 1847

Adinotherium ovinum (Owen, 1853)

Hegetotherium mirabile Ameghino, 1887a

Pachyrukhos moyani Ameghino, 1885

Protypotherium australe Ameghino, 1887b

Protypotherium praerutilum Ameghino, 1887a

Protypotherium attenuatum Ameghino, 1887a Interatherium sp.

Anisolophus australis (Burmeister, 1879)

Anisolophus floweri (Ameghino, 1887a)

Tetramerorhinus lucarius Ameghino, 1894

Tetramerorhinus cingulatum (Ameghino, 1891)

Thoatherium minusculum Ameghino, 1887a

Diadiaphorus majusculus Ameghino, 1887a

Theosodon sp.

Acarechimys minutus (Ameghino, 1887a)

Acarechimys minutissimus (Ameghino, 1887a)

Acarechimys constans (Ameghino, 1887a)

Acarechimys gracilis (Ameghino, 1891)

Dudumus sp. nov.?

Prospaniomys sp. nov.?

Stichomys regularis Ameghino, 1887a

Spaniomys riparius Ameghino, 1887a

Acaremys murinus Ameghino, 1887a

Sciamys principalis Ameghino, 1887a

Sciamys latidens Scott, 1905

Steiromys detentus Ameghino, 1887a

Steiromys duplicatus Ameghino, 1887a

Neoreomys australis Ameghino, 1887a

Eocardia montana Ameghino, 1887b

"Eocardia" excavata Ameghino, 1891

Schistomys erro Ameghino, 1887a

Phanomys mixtus Ameghino, 1887a

Prolagostomus pusillus Ameghino, 1887a

Pliolagostomus notatus Ameghino, 1887a

Perimys erutus Ameghino, 1887a

Perimys onustus Ameghino, 1887a

Perimys incavatus Ameghino, 1902

Scleromys sp.

Homunculus vizcainoi sp.nov. Kay and Perry, 2019 


\begin{abstract}
Appendix 2. Comparison of the compiled list of mammal species in the new collections of Santa Cruz Formation at the Río Santa Cruz (RSC) reported in the volume edited by Fernicola et al. (2019b), with previous reports from the RSC and the Atlantic Coast. It includes taxa identified at the genus or higher level only when one species of the genus has not been recorded before for the area considered (i.e., the record of the genus implies at least the presence of one species, e.g., Eucinepeltus sp.).
\end{abstract}

Old Collections: list of mammals from old collections of the RSC; New Collections: list of mammals from the new collections from the RSC in Fernicola et al. (2019b); Barrancas Blancas (BB), Segundas Barrancas Blancas (SBB), and Yaten Huageno (YH). Atlantic Coast: list of taxa from the new collections of the RSC also recorded in outcrops of the SCF from the Atlantic Coast between National Park Monte León and Río Gallegos.

\begin{tabular}{|c|c|c|c|c|c|c|}
\hline & \multicolumn{2}{|c|}{ Río Santa Cruz } & \multicolumn{3}{|c|}{ Río Santa Cruz localities } & \multirow[t]{2}{*}{ Atlantic Coast } \\
\hline & Old Collections & New Collections & $B B$ & $S B B$ & $Y H$ & \\
\hline \multicolumn{7}{|l|}{ METATHERIA } \\
\hline \multicolumn{7}{|l|}{ SPARASSODONTA } \\
\hline Cladosictis patagonica & $x^{1}$ & $X^{11}$ & - & $X^{11}$ & - & $X^{13}$ \\
\hline Sipalocyon gracilis & $x^{1}$ & $X^{11}$ & $X^{11}$ & $X^{11}$ & - & $X^{13}$ \\
\hline Perathereutes pungens & - & $X^{11}$ & - & $X^{11}$ & - & $x^{13}$ \\
\hline Acrocyon sectorius & $x^{1}$ & - & - & - & - & - \\
\hline Acyon tricuspidatus & $x^{1}$ & - & - & - & - & - \\
\hline Borhyaena tuberata & $x^{\prime}$ & $x^{11}$ & $x^{11}$ & $X^{11}$ & - & $x^{13}$ \\
\hline Lycopsis torresi & $x^{2}$ & - & - & - & - & - \\
\hline \multicolumn{7}{|l|}{ PAUCITUBERCULATA } \\
\hline Stilotherium dissimile & $x^{1}$ & - & - & - & - & - \\
\hline Abderites meridionalis & $x^{\prime}$ & $x^{11}$ & $x^{11}$ & $X^{11}$ & - & $x^{11}$ \\
\hline Acdestis oweni & $x^{\prime}$ & $x^{11}$ & $x^{11}$ & $X^{11}$ & - & $x^{13}$ \\
\hline Palaeothentes lemoinei & $x^{1}$ & $X^{11}$ & $x^{11}$ & $X^{11}$ & - & $X^{13}$ \\
\hline P. intermedius & $X^{1}$ & $X^{11}$ & $X^{11}$ & $X^{11}$ & - & $X^{11}$ \\
\hline P. minutus & $x^{\prime}$ & $X^{11}$ & $X^{11}$ & $X^{11}$ & - & $X^{13}$ \\
\hline P. aratae & $x^{\prime}$ & - & - & - & - & - \\
\hline \multicolumn{7}{|l|}{ MICROBIOTHERIA } \\
\hline Microbiotherium patagonicum & $x^{1}$ & - & - & - & - & - \\
\hline M. tehuelchum & $x^{\prime}$ & $x^{11}$ & - & $x^{11}$ & - & $x^{13}$ \\
\hline \multicolumn{7}{|l|}{ XENARTHRA } \\
\hline \multicolumn{7}{|l|}{ FOLIVORA } \\
\hline Hapalops elongatus & - & $x^{3}$ & $x^{3}$ & $x^{3}$ & - & $X^{14}$ \\
\hline H. rectangularis & $x^{\prime}$ & - & - & - & - & - \\
\hline H. indifferens & $x^{1}$ & - & - & - & - & - \\
\hline H. rostratus & $x^{1}$ & - & - & - & - & - \\
\hline H. infernalis & $x^{1}$ & - & - & - & - & - \\
\hline H. adteger & $x^{\prime}$ & - & - & - & - & - \\
\hline Schismotherium fractum & $X^{1}$ & $x^{3}$ & - & $x^{3}$ & - & $X^{19}$ \\
\hline Xyophorus atlanticus & - & $x^{3}$ & - & $x^{3}$ & - & $x^{3}$ \\
\hline Planopinae indet. & - & $x^{3}$ & - & $x^{3}$ & - & - \\
\hline Planops longirostratus & $x^{\prime}$ & - & - & - & - & - \\
\hline Eucholoeops ingens & $x^{1}$ & - & - & - & - & - \\
\hline Nematherium angulatum & $X^{1}$ & - & - & - & - & - \\
\hline N. longirostris & - & $x^{3}$ & - & $x^{3}$ & - & $x^{3}$ \\
\hline \multicolumn{7}{|l|}{ CINGULATA } \\
\hline Peltephilus pumilus & $x^{1}$ & $x^{4}$ & $x^{4}$ & $x^{4}$ & - & $X^{13}$ \\
\hline P. strepens & $x^{1}$ & - & - & - & - & - \\
\hline Stegotherium tessellatum & $x^{\prime}$ & $x^{4}$ & $x^{4}$ & - & - & - \\
\hline Prozaedyus proximus & $x^{\prime}$ & $x^{4}$ & $x^{4}$ & $x^{4}$ & $x^{4}$ & $x^{13}$ \\
\hline Stenotatus patagonicus & $x^{1}$ & $x^{4}$ & $X^{4}$ & $x^{4}$ & $X^{4}$ & $X^{13}$ \\
\hline
\end{tabular}


Continuated

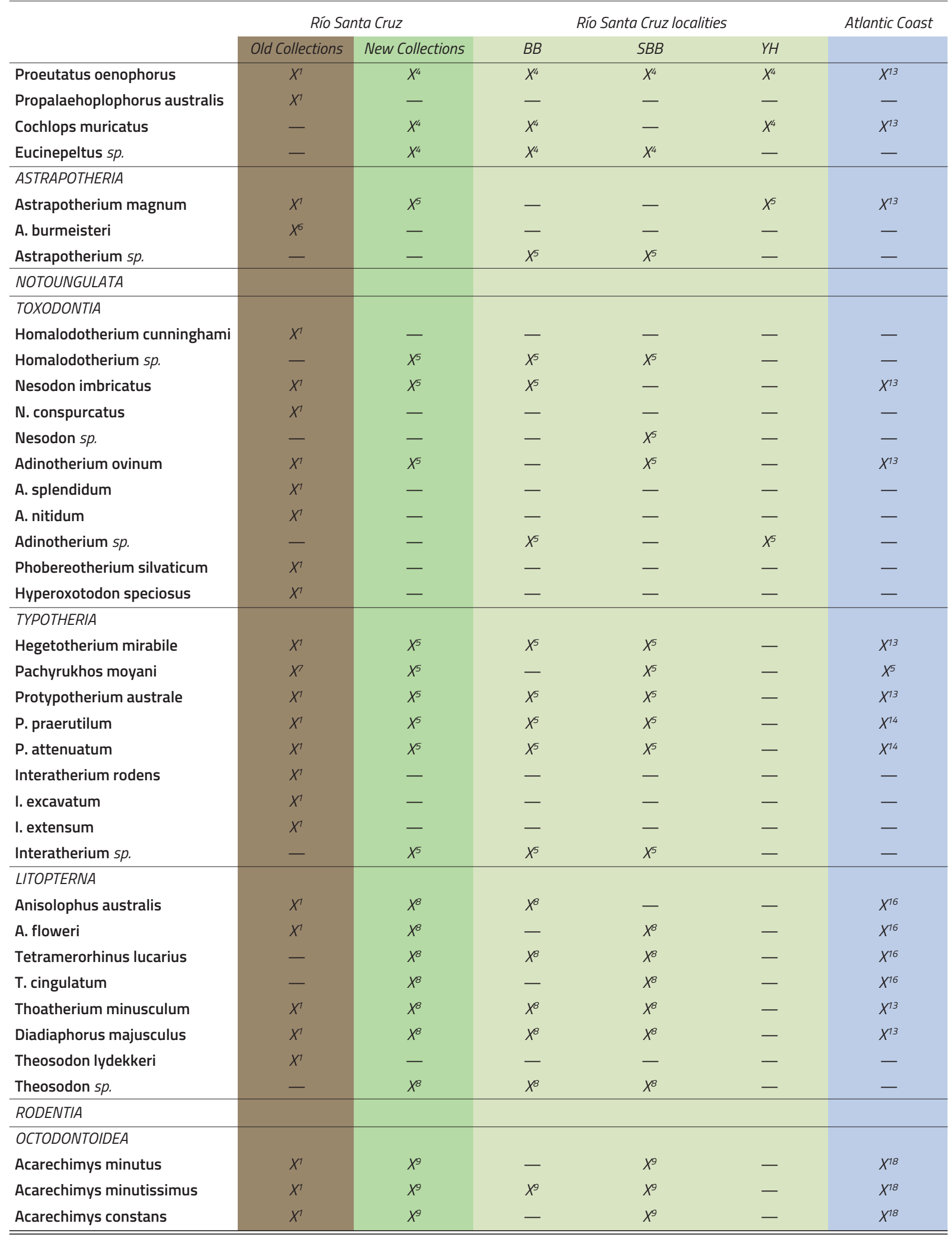


Continuated

\begin{tabular}{|c|c|c|c|c|c|c|}
\hline & \multicolumn{2}{|c|}{ Río Santa Cruz } & \multicolumn{3}{|c|}{ Río Santa Cruz localities } & \multirow[t]{2}{*}{ Atlantic Coast } \\
\hline & Old Collections & New Collections & $B B$ & $S B B$ & $Y H$ & \\
\hline Acarechimys gracilis & - & $x^{9}$ & - & $X^{9}$ & - & $x^{18}$ \\
\hline Dudumus sp. nov.? & - & $x^{9}$ & - & $X^{9}$ & - & - \\
\hline Prospaniomys sp. nov.? & - & $x^{9}$ & $X^{9}$ & $X^{9}$ & - & - \\
\hline Stichomys regularis & $x^{1}$ & $x^{9}$ & - & $x^{9}$ & $x^{9}$ & $X^{15}$ \\
\hline Stichomys $s p$. & - & - & $x^{9}$ & - & - & - \\
\hline Spaniomys riparius & $X^{1}$ & $x^{9}$ & $X^{9}$ & $X^{9}$ & - & $X^{14}$ \\
\hline Spaniomys sp. & - & - & - & - & $x^{9}$ & - \\
\hline Spaniomys modestus & $x^{1}$ & - & - & - & - & - \\
\hline Adelphomys candidus & $x^{7}$ & - & - & - & - & - \\
\hline Acaremys murinus & $X^{1}$ & $X^{9}$ & - & $X^{9}$ & - & $X^{18}$ \\
\hline Acaremys messor & $x^{1}$ & - & - & - & - & - \\
\hline Acaremys sp. & - & - & $x^{9}$ & - & - & - \\
\hline Pseudoacaremys kramarzii & $X^{13}$ & - & - & - & - & - \\
\hline Sciamys principalis & $X^{1}$ & $x^{9}$ & $X^{9}$ & $X^{9}$ & - & $X^{17}$ \\
\hline Sciamys latidens & - & $x^{9}$ & - & $x^{9}$ & - & $X^{18}$ \\
\hline Sciamys varians & $x^{1}$ & - & - & - & - & - \\
\hline \multicolumn{7}{|l|}{ ERETHIZONTOIDEA } \\
\hline Steiromys detentus & $x^{1}$ & $x^{9}$ & $x^{9}$ & $x^{9}$ & - & $X^{13}$ \\
\hline Steiromys duplicatus & $X^{7}$ & $x^{9}$ & $X^{9}$ & $X^{9}$ & - & $X^{13}$ \\
\hline \multicolumn{7}{|l|}{ CAVIOIDEA } \\
\hline Neoreomys australis & $x^{1}$ & $x^{9}$ & $x^{9}$ & $X^{9}$ & $x^{9}$ & $X^{13}$ \\
\hline Eocardia montana & $x^{1}$ & $x^{9}$ & $x^{9}$ & $x^{9}$ & - & $X^{13}$ \\
\hline "Eocardia" excavata & - & $x^{9}$ & $x^{9}$ & $X^{9}$ & - & $X^{14}$ \\
\hline "Eocardia" fissa & $x^{20}$ & - & - & - & - & - \\
\hline Schistomys erro & $X^{1}$ & $X^{9}$ & - & $X^{9}$ & - & $x^{20}$ \\
\hline Phanomys mixtus & $X^{1}$ & $x^{9}$ & $x^{9}$ & - & - & - \\
\hline Phanomys sp. & - & - & - & $x^{9}$ & - & - \\
\hline \multicolumn{7}{|l|}{ CHINCHILLOIDEA } \\
\hline Prolagostomus pusillus & $X^{1}$ & $x^{9}$ & - & $X^{9}$ & - & $x^{21}$ \\
\hline Prolagostomus $s p$ & - & - & $x^{9}$ & - & - & - \\
\hline Pliolagostomus notatus & $X^{\top}$ & $x^{\rho}$ & - & $x^{9}$ & - & $x^{21}$ \\
\hline Perimys erutus & $x^{1}$ & $x^{9}$ & $X^{9}$ & $x^{9}$ & - & $X^{14}$ \\
\hline Perimys onustus & $x^{1}$ & $x^{9}$ & $x^{9}$ & $X^{9}$ & - & - \\
\hline Perimys incavatus & - & $x^{9}$ & $X^{9}$ & - & - & - \\
\hline Perimys zonatus & $X^{1}$ & - & - & - & - & - \\
\hline Scleromys angustus & $x^{\prime}$ & - & - & - & - & - \\
\hline Scleromys sp. & - & $x^{9}$ & $X^{9}$ & $X^{9}$ & - & - \\
\hline \multicolumn{7}{|l|}{ PRIMATES } \\
\hline Homunculus vizcainoi $s p$. nov. & - & $x^{10}$ & $x^{10}$ & $X^{10}$ & - & - \\
\hline TOTAL N N OF SPECIES $S^{(*)}$ & 79 & 64 & 47 & 60 & 9 & - \\
\hline
\end{tabular}

$X^{1}$ : Ameghino, 1887a; X2: Cabrera, 1927; $X^{3}$ : Bargo et al., 2019; $X^{4}$ : Fernicola and Vizcaíno, 2019; X5: Fernández and Muñoz, 2019; $X^{6}$ : Mercerat, 1891; $X^{7}$ : Ameghino, 1885; $X^{8}$ : Schmidt et al., 2019; $X^{9}$ : Arnal et al., 2019; $X^{10}$ : Kay and Perry, 2019; $X^{11}$ : Chornogubsky et al., 2019; $X^{12}$ : Arnal and Vucetich, 2015; $X^{13}$ : Kay et al., 2012; $X^{14}$ : Tauber, 1997a; $X^{15}$ Tauber, 1996; $X^{16}$ : Soria, 2001; $X^{17}$ : Arnal, 2012; $X^{18}$ : Arnal et al., 2017; $X^{19}$ : Racco et al., 2018; $X^{20}$ : Pérez, 2010; $X^{21}$ : Rasia, 2016.

(") species + species inferred from specimens identified at generic or suprageneric level 